\title{
MEAL AND OIL QUALITY AMONG GENOTYPES OF INDIAN MUSTARD (BRASSICA JUNCEA) VARIES UNDER RECOMMENDED DOSE OF NITROGEN FERTILIZER
}

\author{
Mawlong, I. ${ }^{1}{ }^{*}-$ Sujith Kumar, M. S. ${ }^{1}-$ KAndPal, B. K. ${ }^{1,2}-$ Premi, O. P. ${ }^{1}-$ Gurung, B. ${ }^{3}-$ \\ SINGH, D. ${ }^{1}$ \\ ${ }^{1} I C A R$ - Directorate of Rapeseed-Mustard Research \\ Bharatpur 321303, Rajasthan, India \\ ${ }^{2} I C A R$ - Research Complex for North Eastern Region, Tripura Centre \\ Lembucherra 799201, India \\ ${ }^{3}$ ICAR - Indian Agricultural Statistics Research Institute \\ New Delhi 110012, India \\ *Corresponding author \\ e-mail: iban02@gmail.com; phone: +05644-260379/260495 \\ (Received $15^{\text {th }}$ May 2017; accepted $25^{\text {th }}$ Jul 2017)
}

\begin{abstract}
Out of the 24 genotypes of Indian mustard $63 \%$ showed increase in total seed nitrogen content after $80 \mathrm{~kg} \mathrm{~N}(\mathrm{~N} 80)$ application while $37 \%$ showed a decrease compared to control (N0). In some genotypes the increase in total seed nitrogen content under $\mathrm{N} 80$ had no influence on total soluble protein. About $88 \%$ genotypes showed reduction in crude fiber by $1.10 \%$ (GM-2) to $35.6 \%$ (DRMR-IJ-31) and in all 24 genotypes soluble sugars also reduced by 8\% (Maya) to 80\% (HB-9912) suggesting the influence of $\mathrm{N}$ application on digestibility of meal. Profiling of seed storage proteins showed differences in banding patterns in treated samples with prominent changes in $\alpha$ and $\beta$ chains of cruciferin. In case of SFA and $\omega 6: \omega 3$ ratio, $50 \%$ of genotypes showed increase while $50 \%$ genotypes showed a decrease in their SFA and $\omega 6: \omega 3$ ratio compared to control. Oil stability index also increased in $63 \%$ of the genotypes under N80. Undesirable Erucic acid was found to increase in $58 \%$ of the genotypes by $0.98 \%$ (DHR-991) to $38.31 \%$ (HB-9902) and in rest of the $42 \%$ it reduced by $1.14 \%$ (DRMR-IJ31) to $22.55 \%$ (NRCDR-2) over control (N0).
\end{abstract}

Keywords: total phenol, ascorbic acid, total soluble sugars, crude fiber, seed storage protein

\section{Introduction}

Indian mustard is a winter oilseed crop largely grown in semi-arid regions of northern India. It is considered healthy and ideal for cooking because of low saturated fatty acid (SFA), high monounsaturated fatty acid (MUFA), moderate polyunsaturated fatty acid (PUFA) content, ideal $\omega 6 / \omega 3$ ratio, low acid value, low saponification value and high smoke point. Besides high quality oil, the seed meal has high protein content which is ideal for animal feed or even fit for human consumption (Wanasundara, 2011). The high protein content also implies a high absorption of nitrogen from the soil which makes nitrogen fertilizers very important for this crop.

Plants take up nitrogen in the form of nitrate, as well as ammonium, this in turn can modulate the uptake of other anions and cations causing a change in the primary and secondary metabolic process and consequently the quality of oil and meal. Optimization of nitrogen application is important for the synthesis of C-based phytochemicals, including natural antioxidants such as phenolic groups (Björkman et al., 2011). Some 
reports have shown decrease in phenol content under higher doses of nitrogen fertilizers (Li et al., 2008; Giorgi et al., 2009; Zaghdoud et al., 2016) while Tavarini et al. (2015) have observed increase in phenolic content up to a certain level of nitrogen dose. Likewise, ascorbic acid content is found to vary with nitrogen treatments in different Brassica crops like cabbage (Roni et al., 2015) and cauliflower (Lisiewska and Kmiecik, 1996). Ascorbic acid being an essential vitamin which needs to be obtained through diet is very important as an antioxidant and for synthesis of collagens L-carnitine and conversion of dopamine to norepinephrine.

There is one report of soluble sugars such as stachyose, raffinose and sucrose in diet causing flatulence in animals and digestive problems in poultry (Hartwig et al., 1997). Since seed meal from mustard has been suggested as a protein source for livestock, aquaculture and also for human consumption (Wanasundara, 2011), it is also necessary to look for potential anti nutritional factors in it. Also more emphasis should be given to soluble proteins than total proteins as they add more value to the seed meal. For example it is important to know the amount of storage proteins like albumin and globulin as they can be used for fortification of food products. Low fiber meal is preferred for animal feed because it increases the digestibility and palatability of the feed. The low metabolizable energy of mustard seed meal $(2000 \mathrm{kcal} / \mathrm{kg})$ compared to that of soybean $(2230 \mathrm{kcal} / \mathrm{kg})$ is one of the reasons for considering mustard seed meal as inferior (Suprianto, 2014).

Increasing population and dwindling natural resources have promoted the excess use of fertilizers. High yielding varieties of crops also demand heavy use of fertilizers which results in irreversible degradation of soil and natural resources. Excessive use of fertilizers also contributes to global warming. There have been numerous studies that relate fertilizer use and its effect on yield and oil content of oilseed Brassica (Joshi et al., 1998; Parmar and Parmar, 2012). However, little is known about the effect of fertilizer application on chemical composition of oil and seed meal.

Keeping this in view, in this study we have tried to see the effect of nitrogen fertilizer on the nutritional quality of oil and seed meal. In many of the mustard growing regions in India, use of $80 \mathrm{~kg} \mathrm{~N} / \mathrm{ha}$ has been recommended to enhance the productivity of mustard (Shekhawat et al., 2012). No data to our knowledge are available on the study of nutritional composition of oil and meal in relation with nitrogen fertilizer application in Indian mustard. Such studies can open new avenues for future research and proper documentation pertaining to Indian mustard.

\section{Materials and methods}

\section{Experimental site}

The experiment was conducted at ICAR-Directorate of Rapeseed Mustard Research (DRMR) Bharatpur $\left(27^{\circ} 11^{\prime} \mathrm{N}\right.$ Lat. and $77^{\circ} 27^{\prime} \mathrm{E}$ Long.); India, during 2013-15. The climate of the region is predominantly semi-arid with long hot summers, intermittent short rainy period due to south-west monsoon and almost 5 month long winter when average temperature drops to below $22.5^{\circ} \mathrm{C}$. The winter season often coincides with one or two rains due to western disturbances. The soils of the region are mainly coarse to fine loamy, deep, well drained Inceptisols and fallow-mustard is the predominant cropping system of the region. In general, the soils of the experimental site was alkaline ( $\mathrm{pH} 8.1)$, low in exchangeable salts $(\mathrm{EC} 0.6 \mathrm{dS} / \mathrm{m})$, organic carbon content $(2.6 \mathrm{~g} / \mathrm{kg}$ ), available $\mathrm{N}\left(95.4 \mathrm{~kg} \mathrm{~N} / \mathrm{ha} \mathrm{KMnO}_{4}\right.$ oxidisable) and available $\mathrm{P}(5.4 \mathrm{~kg} \mathrm{P} / \mathrm{ha} 0.5 \mathrm{~N}-$ 
$\mathrm{NaHCO}_{3}$ extractable); and high in available $\mathrm{K}\left(267 \mathrm{~kg} 1 \mathrm{~N}-\mathrm{NH}_{4} \mathrm{OAC}\right.$ exchangeable $\mathrm{K}_{2} \mathrm{O} / \mathrm{ha}$ ). Initially, the field was put under exhaustive pearl millet (Pennisetum glaucum) - Indian mustard without any external fertilizer inputs for continuous three preexperimentation years. Pennisetum glaucum was sown in the first week of July every year followed by Indian mustard var. Rohini.

\section{Experimental design}

During 2013-14, a replicated trial in split plot design keeping two nitrogen environments ( 0 and $80 \mathrm{~kg} \mathrm{~N} / \mathrm{ha}$ ) in main plot and 108 oilseed Brassica (OSB) genotypes in sub-plot was conducted to screen out low nitrogen requiring germplasms. Based on field and yield attributes, 24 genotypes were found promising. These selected 24 genotypes were further evaluated for detailed growth, yield and biochemical studies during 2014-15 under two distinct $\mathrm{N}$ environments. The genotypes were sown at $5 \mathrm{~cm}$ depth in $30 \mathrm{~cm}$ row spacing with the help of manual plough in subplots $(4.5 \mathrm{~m} \times 5.0 \mathrm{~m}$ ) during second fortnight of October 2014. The plant to plant distance was maintained at $10-15 \mathrm{~cm}$ by thinning at 20-25 days after sowing (DAS). As per the treatment, half dose of nitrogen as urea, full recommended dose of phosphorus in the form of single super phosphate were applied at the time of sowing, and the remaining nitrogen in the form of urea was top dressed after the first irrigation. At maturity, 5 plants were randomly selected from the second and third row from the left side of the plot for recording growth and yield attributes. Harvesting was done by avoiding boarder area and observation lines manually by cutting at surface level using sickles to estimate biological and economic yields. Further, three samples from each plots were collected for all biochemical analysis. Each biochemical parameters for accuracy of data were done in three technical replicates.

\section{Total nitrogen}

The total nitrogen was estimated by miro-kjeldahl (Pro-Nitro A Model of JP Selecta, Spain) method as procedure suggested by AOAC (1955).

\section{Fatty acid profiling}

Fatty acid profiling was carried out as described by Paquot and Hautfenne, (1987) with little modification. A Nucon model 5765 gas chromatograph with SP-2300 (2\%) + SP-2310 (3\%) packed silica column was used. The programme was set at $\mathrm{N}_{2}$ flow rate: $30 \mathrm{ml} / \mathrm{min}, \mathrm{H}_{2}$ flow rate: $30 \mathrm{ml} / \mathrm{min}$, Zero air flow rate: $300 \mathrm{ml} / \mathrm{min}$, Injector temp: $240{ }^{\circ} \mathrm{C}$ and Detector (FID) temp: $250{ }^{\circ} \mathrm{C}$. Individual fatty acids were compared to the retention time of standard methyl esters of fatty acids.

\section{Stability index of oils}

Stability index of oils were calculated empirically by the ratio of MUFA: PUFA (Chauhan et al., 2010).

\section{Defattening of seed meal}

Oil was extracted from ground seeds after homogenizing with n-hexane using pestle and mortar at room temperature. This was repeated for three to four times to ensure 
complete extraction of oil. The seed meal was dried till hexane is completely removed and stored at $4{ }^{\circ} \mathrm{C}$.

\section{Total phenols and crude fiber}

Total phenols and crude fiber were estimated by non destructive method using FTNIR-Bruker (model Matrix-1) as described by Bala and Singh (2013).

\section{Vitamin C (Ascorbic Acid)}

Ascorbic acid was estimated using the titrimetric method described by Ranganna (1986). $0.1 \mathrm{~g}$ of the defatted seed meal was homogenized with $3 \% \mathrm{HPO}_{3}$ and final volume made to $10 \mathrm{ml}$. The supernatant was collected into glass vials after centrifugation for $10 \mathrm{~min}$ at $5000 \mathrm{rpm}$. Aliquot of the extract was taken in a $25-50 \mathrm{ml}$ conical flask and titrated against the standardized dye (2,6 -dichlorophenol indophenol) till persistent pink color was detected that lasted for $5 \mathrm{~s}$. Vitamin $\mathrm{C}$ was calculated using the following formula.

$$
\mathrm{mg} \text { of ascorbic acid } / 100 \mathrm{~g}=\frac{\text { Titre } x \text { Dye Factor } x \text { Final wolume made up }}{\text { Aliquot of extract taken } x \text { Weight of sample taken }}
$$

\section{Total antioxidant capacity}

Total antioxidant capacity (TAC) was determined as per Prieto et al. (1999). $100 \mathrm{mg}$ of defatted seed meal was dissolved in $80 \%$ methanol overnight. The supernatant was collected after centrifuging at $4000 \mathrm{rpm}$ for $10 \mathrm{~min}$ and final volume was raised to $2 \mathrm{ml}$. Reduction of Mo(VI) to Mo (V) and the subsequent formation of green colour complex was measured by spectrophotometer (Labomed UV-VIS Double beam UVD-3500) at $695 \mathrm{~nm}$ and is expressed as ascorbic acid equivalent (AAE).

\section{Total soluble sugars}

Total soluble sugars were estimated as per protocol of Hansen and Møller (1975). $100 \mathrm{mg}$ of defatted seed meal was homogenized with $100 \%$ acetone by vortexing. After centrifugation the residue was washed with hot ethanol (80\%). This was repeated twice. Supernatant was collected and final volume was raised to $2 \mathrm{ml}$ with $80 \%$ ethanol. This extract was used for the estimation of total soluble sugar by Anthrone method whose absorbance was taken at $620 \mathrm{~nm}$.

\section{Total soluble protein}

Soluble protein content in the defatted seeds was estimated by the method of Lowry et al. (1951) after precipitation with trichloroacetic acid. Soluble protein was resuspended in laemmili lysis buffer denatured at $95^{\circ} \mathrm{C}$ for $4 \mathrm{~min}$.

\section{Gel electrophoresis}

SDS-PAGE of seed storage protein was carried out in a $12 \%$ Polyacrylamide gel in a discontinuous buffer system. $15 \mu \mathrm{l}(20 \mu \mathrm{g} / \mu \mathrm{l})$ was loaded in each well of the stacking gel. Wide range prestained protein ladder was run as reference. The gel was stained with solution containing of $2 \%$ Coomassie Brilliant Blue, followed by destaining after $1 \mathrm{~h}$ with mixture of methanol, acetic acid and water (5:1:4). 


\section{Statistical analysis}

The data obtained under different treatments with respect to various parameters were subjected to Analysis of Variance (ANOVA) using SAS 9.3 software package.

Pair-wise comparisons on the least squares mean (LSMEANS) were performed using the Tukey's honest significant difference (HSD) test.

\section{Results and discussion}

\section{Application of nitrogen influences the nutritional quality of meal}

Total nitrogen content in seed

Studies on the effect of nitrogen on quality traits have been carried out in leaves of $B$. juncea and B. rapa (Fallovo et al., 2011), cabbage (Leja et al., 2007), curly kale (Groenbaek et al., 2016) and broccoli (Zaghdoud et al., 2016), but not many reports on effect of applied nitrogen on quality of seed and oil are available. In our study, total seed nitrogen content ranged from 2.86 \% (Maya and RL-1359) to 3.95\% (EC399300) at zero nitrogen (N0) application and 3.1\% (RL-1359) to $4.3 \%$ (IC212031) at $80 \mathrm{~kg}$ $\mathrm{N} /$ ha (N80) (Table 1). About $63 \%$ of the genotypes showed increase in total seed nitrogen by $3 \%$ (DRMR-IJ-31) to $34.0 \%$ (NRCDR-2) over N0.The increase in total seed $\mathrm{N}$ content was proportional to the increase in total soluble protein which varied from $1 \%$ (Maya) to $34 \%$ (NRCDR-2), with a confirmation of a positive correlation $(\mathrm{r}=0.33$, p0.019) (Table 2.a). Though, exceptions in some genotypes showed reduction in soluble protein by $4 \%(78-1-1-1)$ to $16 \%$ (NATP-124 and RGN-55) (Table 1). The decrease in soluble protein, even when there is increase in nitrogen intake, could be due to the partition of nitrogen towards the synthesis of other carbon containing compounds in TCA cycle as it shares common substrates. This is substantiated, by increase in ascorbic acid (14. $29 \%$ to $50 \%)$ and phenol $(1.14 \%$ to $14 \%)$ content (Table 1). However, rest of the $37 \%$ genotypes showed decrease in seed N content at N80 by 5.6 $\%$ (HB9916) to $20.2 \%$ (EC399300) over N0. These are the genotypes that also showed a reduction in soluble proteins from $5 \%$ (78-1-1-1, NRCHB-101, HB9916) to $16 \%$ (RGN-55) and could be less responsive to nitrogen uptake. According to Chopin et al. (2007) in Arabidopsis there are high and low affinity nitrate transporters that regulate the uptake of nitrogen into plants. Our study also found genotypes such as EC399294 (5\%), EC399307 (14\%) and GM-2 (7\%) that showed an increase in soluble proteins in spite of low content nitrogen. This interplay of nitrogen fertilization $\times$ genotype $\times$ quality trait needs more in-depth investigation.

\section{Total phenol content}

Natural antioxidants and their use as food additives or supplements has been a hot topic in recent years. Members of Brassica family are known to possess health promoting phytochemicals, especially those with antioxidant properties. Among the phytochemicals, phenolic compounds are very important due to their antioxidant properties (Björkman et al., 2011).

The total phenol content in our study ranged from $1.35 \%$ (RL-1359) to $2.26 \%$ (Rohini) under N0 and from $1.46 \%$ (HB-9902) to $2.18 \%$ (DRMR-IJ-31) under N80 (Table 1). There are reports of decrease in phenol content under higher doses of nitrogen fertilizer (Li et al., 2008, Giorgi et al., 2009; Zaghdoud et al., 2016) which was also 
observed in our study as the phenol content reduced by $0.83 \%$ (QM-16) to $21.83 \%$ (Rohini) in about $33 \%$ of genotypes (Table 1). This reduction in phenol content as reported by Ibrahim et al. (2011) could be due to inhibition of phenylalanine ammonia lyase (PAL) at higher levels of nitrogen or may be due to diversion of metabolites in the direction of protein synthesis. As expected, $63 \%$ of our genotypes increased in phenol content by $1.14 \%$ (GM-2) to $14.01 \%$ (RL-1359) over N0 application (Table1). Our studies is in tune with work by Groenbaek et al. (2016) in traditional kale. Surprisingly, $4 \%$ of our genotype showed no change in phenol content after N80 application. It is interesting to note within the same species the effect of nitrogen can have varied effects on the phenol content.

This discrepancy between different reports could be due to the differences in the form of nitrogen fertilizers (nitrate or ammoniacal) applied. Fallovo et al. (2011) reported increase in phenol content in the leaves of B. juncea and B. rapa due to forms of $\mathrm{N}$ fertilizer. Leja et al. (2007) observed decrease in concentration of phenolic compounds in cabbage head which were fertilized using calcium nitrate, ammonium sulphate, ammonium nitrate and urea by broadcasting. However, Smolen and Sady (2009) observed rise in phenolic concentration in carrots irrespective of the type and mode of nitrogen application. Sousa et al. (2008) have reported the profile of phenolic compounds to have varied even within the plant organ of the same Brassica species.

Our study suggests that variation in total phenol content is due to genetic variability that determines the optimization of nitrogen uptake and in turn alters the biochemical composition. According to Nguyen and Niemeyer (2008) in basil (Ocimum basillicum L.) phenolic content is a genotype dependent property. In this study more number of cultivars were analysed unlike the works reported previously in one or two cultivars.

\section{Vitamin C (Ascorbic acid)}

Another important natural antioxidant studied was ascorbic acid, an essential nutrient usually obtained from fruits and vegetables. The biological functions of ascorbic acid include radical scavenging, electron transport in plasma membrane and as cofactor in biosynthesis of collagen and conversion of dopamine to norepinephrine. It can scavenge superoxide and hydroxyl radicals besides regenerating $\alpha$-tocopherol.

Our study on Indian mustard genotypes, showed significant variation in ascorbic acid content from $43 \mathrm{mg} / 100 \mathrm{~g}$ to $172 \mathrm{mg} / 100 \mathrm{~g}$ seed meal (Table 1). However, about $58 \%$ of the genotypes showed ascorbic acid content to increase by $14.29 \%$ (HB9916) to $50 \%$ (EC399307, NATP-124, NRCDR-2, BEC-16), about $21 \%$ genotypes showed decrease in ascorbic acid content by $20 \%$ (QM-16) to $100 \%$ (HB-9902) and the rest $21 \%$ of the genotypes did not show any change. Increase in ascorbic acid content upon nitrogen treatment has also been reported in cabbage (De and Shankar, 1987). Decrease in ascorbic acid in cabbage (Freyman et al., 1991) and cauliflower (lisiewska and Kmiecik, 1996) have also been reported. The variation in ascorbic acid content could be due to their sensitivity to the enzyme GDP-Mannose pyrophosphorylase, an enzyme essential for the synthesis of metabolite GDP-Mannose, a precursor of ascorbic acid which has been confirmed in model plant to be hypersensitive to $\mathrm{NH}_{4}{ }^{+}$and is a genetic determinant for $\mathrm{NH}_{4}{ }^{+}$sensitivity (Qin et al., 2008). As we have also observed not all genotypes studied had the same levels of nitrogen in seed. This could be the reason for differences in ascorbic acid among the different genotypes. Our study is the first of its kind done in Indian mustard and more enquiries are needed to prove whether there is any dose dependent effect of nitrogen application on ascorbic acid content in seed meal. 
Table 1. Biochemical Composition of 24 genotypes of B. juncea at NO and N80 application

\begin{tabular}{|c|c|c|c|c|c|c|c|c|c|c|c|c|c|c|}
\hline \multirow[t]{2}{*}{ Genotypes } & \multicolumn{2}{|c|}{$\begin{array}{c}\text { Total nitrogen } \\
(\%)\end{array}$} & \multicolumn{2}{|c|}{$\begin{array}{c}\text { Total phenols } \\
(\%)\end{array}$} & \multicolumn{2}{|c|}{ 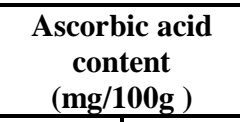 } & \multicolumn{2}{|c|}{$\begin{array}{c}\text { Total antioxidant } \\
\text { capacity } \\
(\mathbf{m g} / \mathbf{g} \text { AAE }) \\
\end{array}$} & \multicolumn{2}{|c|}{$\begin{array}{c}\text { Total soluble } \\
\text { sugars } \\
(\mathrm{mg} / \mathrm{g}) \\
\end{array}$} & \multicolumn{2}{|c|}{$\begin{array}{c}\text { Total crude fiber } \\
(\%)\end{array}$} & \multicolumn{2}{|c|}{$\begin{array}{l}\text { Total soluble protein } \\
(\%)\end{array}$} \\
\hline & No & N80 & No & N80 & NO & N80 & No & N80 & No & N80 & No & N80 & No & N80 \\
\hline $\begin{array}{c}\text { DRMR-IJ- } \\
31\end{array}$ & $3.72^{\mathrm{abcd}}$ & $3.85^{\mathrm{abc}}$ & $1.93^{\mathrm{a}}$ & $2.18^{\mathrm{a}}$ & $71.67^{f}$ & $86.00 \mathrm{e}$ & $39.67^{\text {onp }}$ & $46.83^{\text {fgh }}$ & $178.33^{q}$ & $133.33^{x}$ & $8.84^{\text {nmopqr }}$ & $5.69^{\mathrm{u}}$ & $13.97^{\mathrm{w}}$ & $16.76^{\mathrm{qprst}}$ \\
\hline Maya & $2.86^{\mathrm{abcd}}$ & $3.58^{\mathrm{d}}$ & $1.75^{\mathrm{a}}$ & $1.71^{\mathrm{a}}$ & $107.50^{\mathrm{c}}$ & $86.00 \mathrm{e}$ & $39.83^{\text {onp }}$ & $34.33^{\mathrm{rq}}$ & $243.33^{\mathrm{g}}$ & $223.33^{k}$ & $9.24^{\mathrm{ijklmnop}}$ & $8.99^{\mathrm{klmnop}}$ & $15.44^{\mathrm{tuvw}}$ & $15.59^{\text {stuvw }}$ \\
\hline 78-1-1-1 & $3.55^{\mathrm{abcd}}$ & $3.31^{\mathrm{bcd}}$ & $1.72^{\mathrm{a}}$ & $1.74^{\mathrm{a}}$ & $43.00^{\mathrm{i}}$ & $43.00^{\mathrm{i}}$ & $45.75^{\text {jihg }}$ & $40.00^{\text {on }}$ & $143.33^{\mathrm{w}}$ & $131.11^{\mathrm{y}}$ & $10.3^{\text {defghijklmn }}$ & $9.18^{\mathrm{klmnopqr}}$ & $17.11^{\mathrm{mnopqrs}}$ & $16.42^{\text {qrstu }}$ \\
\hline DHR-991 & $3.4^{\mathrm{abcd}}$ & $3.58^{\mathrm{abcd}}$ & $1.76^{\mathrm{a}}$ & $1.675^{\mathrm{a}}$ & $64.50^{\mathrm{g}}$ & $86.00^{\mathrm{e}}$ & $45.50^{\mathrm{jih}}$ & $45.00^{\mathrm{jik}}$ & $546.67^{\mathrm{a}}$ & $404.44^{\mathrm{b}}$ & $9.85^{\text {efghijklmn }}$ & $9.34^{\text {hijklmnop }}$ & $15.67^{\text {stuv }}$ & $18.43^{\mathrm{ijklmn}}$ \\
\hline EC399294 & $3.68^{\mathrm{abcd}}$ & $3.12^{\mathrm{bcd}}$ & $1.67^{\mathrm{a}}$ & $1.83^{\mathrm{a}}$ & $43.00^{\mathrm{i}}$ & $57.33^{\mathrm{h}}$ & $39.83^{\text {onp }}$ & $46.00^{\text {fing }}$ & $108.33^{\mathrm{a}}$ & $81.11^{\mathrm{f}}$ & $8.89^{\text {Imnopqr }}$ & $10.49^{\text {bcdefghijkl }}$ & $21.02^{\text {edf }}$ & $22.09^{\mathrm{bdc}}$ \\
\hline EC399300 & $3.95^{\mathrm{ab}}$ & $3.15 b^{c d}$ & $1.76^{\mathrm{a}}$ & $1.84^{\mathrm{a}}$ & $57.33^{\mathrm{h}}$ & $86.00^{\mathrm{e}}$ & $47.33^{\mathrm{efg}}$ & $51.50^{\mathrm{c}}$ & $74.44^{\mathrm{g}}$ & $62.22^{\mathrm{i}}$ & $9.8^{\text {efghijklmn }}$ & 9.59 ghijklmno & $18.65^{\mathrm{hijklm}}$ & $21.23^{\mathrm{edc}}$ \\
\hline EC399307 & $2.94^{\mathrm{dc}}$ & $3.54^{\mathrm{abcd}}$ & $1.84^{\mathrm{a}}$ & $2.01^{\mathrm{a}}$ & $86.00^{\mathrm{e}}$ & $172.00^{\mathrm{a}}$ & $39.67^{\text {onp }}$ & $54.33^{\mathrm{b}}$ & $143.33^{\mathrm{w}}$ & $60.00^{\mathrm{j}}$ & $8.76^{\text {nmnopqr }}$ & $6.22^{\text {tu }}$ & $18.02^{\mathrm{ijklmnopq}}$ & $15.92^{\text {rstuv }}$ \\
\hline GM-2 & $3.85^{\mathrm{abc}}$ & $3.15^{\mathrm{bcd}}$ & $1.73^{\mathrm{a}}$ & $1.75^{\mathrm{a}}$ & $86.00^{\mathrm{e}}$ & $86.00^{\mathrm{e}}$ & $44.17^{\mathrm{jkl}}$ & $42.67^{\mathrm{ml}}$ & $276.67^{d}$ & $66.67^{\mathrm{h}}$ & $8.17^{\text {opqrs }}$ & $8.08^{\mathrm{pqrs}}$ & $18.22^{\mathrm{ijk} k \mathrm{mnop}}$ & $19.47^{\text {fghi }}$ \\
\hline Rohini & $3.12^{\mathrm{bcd}}$ & $3.97^{\mathrm{ab}}$ & $2.26^{\mathrm{a}}$ & $1.855^{\mathrm{a}}$ & $71.67^{\mathrm{f}}$ & $43.00^{\mathrm{i}}$ & $48.83^{\mathrm{ef}}$ & $50.67^{\mathrm{c}}$ & $227.78^{j}$ & $165.56^{\mathrm{s}}$ & $7.03^{\text {stu }}$ & $7.53^{\mathrm{rst}}$ & $17.88^{\mathrm{ijklmnopq}}$ & $18.30^{\mathrm{ijk} k m n o}$ \\
\hline HB-207 & $3.64^{\mathrm{abcd}}$ & $3.61^{\mathrm{abcd}}$ & $1.53^{\mathrm{a}}$ & $1.65^{\mathrm{a}}$ & $172.00^{\mathrm{a}}$ & $129.00^{\mathrm{b}}$ & $44.50^{\mathrm{jik}}$ & $47.50^{\mathrm{ef}}$ & $182.22^{0}$ & $126.67^{z}$ & $9.98^{\text {efghijklm }}$ & $10.68^{\text {abcdefghij }}$ & $18.96^{\mathrm{hijkl}}$ & $21.56^{\mathrm{edc}}$ \\
\hline HB-9902 & $3.21^{\mathrm{bcd}}$ & $3.66^{\mathrm{abcd}}$ & $1.46^{\mathrm{a}}$ & $1.46^{\mathrm{a}}$ & $86.00^{\mathrm{e}}$ & $43.00^{\mathrm{i}}$ & $45.00^{\mathrm{jik}}$ & $33.33^{\mathrm{rs}}$ & $97.22^{\mathrm{b}}$ & $60.00^{\mathrm{j}}$ & $10.86^{\text {abcdefghi }}$ & $10.48^{\text {bcdefghijkl }}$ & $17.43^{\mathrm{lmnopqr}}$ & $20.66^{\mathrm{edfc}}$ \\
\hline HB-9912 & $3.92^{\mathrm{abc}}$ & $3.89^{\mathrm{abc}}$ & $1.71^{\mathrm{a}}$ & $1.76^{\mathrm{a}}$ & $43.00^{\mathrm{i}}$ & $43.00^{\mathrm{i}}$ & $23.83^{\mathrm{vw}}$ & $21.83^{\mathrm{yx}}$ & $173.33^{r}$ & $35.00^{\mathrm{k}}$ & $11.07^{\text {abcdefg }}$ & $9.1^{\mathrm{klmnopqr}}$ & $19.11^{\text {ghijk }}$ & $21.27^{\mathrm{edc}}$ \\
\hline
\end{tabular}


Mawlong et al.: Meal and oil quality among genotypes of Indian mustard varies under recommended dose of nitrogen fertilizer

$$
-1434-
$$

\begin{tabular}{|c|c|c|c|c|c|c|c|c|c|c|c|c|c|c|}
\hline HB-9916 & $3.4^{\mathrm{abcd}}$ & $3.21^{\mathrm{bdc}}$ & $1.44^{\mathrm{a}}$ & $1.65^{\mathrm{a}}$ & $86.00^{\mathrm{e}}$ & $100.33^{\mathrm{d}}$ & $20.83^{y}$ & $48.67^{\mathrm{e}}$ & $277.78^{d}$ & $150.00^{\mathrm{v}}$ & $11.64^{\mathrm{abc}}$ & $10.62^{\text {abcdefghij }}$ & $18.59^{\mathrm{hijklm}}$ & $17.60^{\mathrm{jklmnopq}}$ \\
\hline IC212031 & $3.21^{\mathrm{bcd}}$ & $4.3^{\mathrm{a}}$ & $1.66^{\mathrm{a}}$ & $1.69^{\mathrm{a}}$ & $86.00^{\mathrm{e}}$ & $86.00^{\mathrm{e}}$ & $33.17^{\mathrm{rs}}$ & $22.50^{\mathrm{wx}}$ & $133.33^{x}$ & $90.00^{\mathrm{d}}$ & $10.48^{\text {bcdefghijkl }}$ & $9.95^{\text {defghijklm }}$ & $17.04^{\mathrm{mnopqrst}}$ & $18.45^{\mathrm{ijk} \mathrm{kmn}}$ \\
\hline NATP-124 & $3.9^{\mathrm{abc}}$ & $3.94^{\mathrm{ab}}$ & $1.57^{\mathrm{a}}$ & $1.65^{\mathrm{a}}$ & $43.00^{\mathrm{i}}$ & $86.00^{\mathrm{e}}$ & $24.33^{\mathrm{v}}$ & $31.83^{\mathrm{ts}}$ & $261.67^{f}$ & $200.00^{\mathrm{m}}$ & $11.54^{\mathrm{abcd}}$ & $10.82^{\text {abcdefghi }}$ & $24.15^{\mathrm{a}}$ & $20.07^{\mathrm{efgh}}$ \\
\hline QM-16 & $3.36^{\mathrm{abcd}}$ & $3.48^{\mathrm{abcd}}$ & $1.82^{\mathrm{a}}$ & $1.805^{\mathrm{a}}$ & $86.00^{\mathrm{e}}$ & $71.67^{\mathrm{f}}$ & $39.67^{\text {onp }}$ & $23.50^{\mathrm{vw}}$ & $237.78^{\mathrm{h}}$ & $92.22^{\mathrm{c}}$ & $9.81^{\text {efghijklmn }}$ & $8.46^{\text {nopqrs }}$ & $24.25^{\mathrm{a}}$ & $22.84^{\mathrm{abc}}$ \\
\hline RGN-55 & $3.68^{\mathrm{abcd}}$ & $3.2^{7 \mathrm{bcd}}$ & $1.68^{\mathrm{a}}$ & $1.84^{\mathrm{a}}$ & $71.67^{\mathrm{f}}$ & $86.00^{\mathrm{e}}$ & $23.33^{\mathrm{vwx}}$ & $31.17^{\mathrm{t}}$ & $263.33^{\mathrm{e}}$ & $133.33^{x}$ & $10.5^{\text {bcdefghijkl }}$ & $10.21^{\text {cdefghijklm }}$ & $21.01^{\mathrm{edf}}$ & $17.54^{\mathrm{klmnopqr}}$ \\
\hline $\begin{array}{c}\text { NRCHB- } \\
101\end{array}$ & $3.67^{\mathrm{abcd}}$ & $3.4^{\mathrm{abcd}}$ & $1.81^{\mathrm{a}}$ & $1.80^{\mathrm{a}}$ & $57.33^{\mathrm{h}}$ & $86.00^{\mathrm{e}}$ & $30.83^{\mathrm{t}}$ & $28.83^{\mathrm{u}}$ & $160.00^{\mathrm{u}}$ & $80.00^{\mathrm{f}}$ & $9.88^{\text {efghijklmn }}$ & $9.76^{\text {ghijklmno }}$ & $16.89^{\text {nopprst }}$ & $17.79^{\mathrm{jklmnop}}$ \\
\hline NRCDR-2 & $3.19^{\mathrm{bcd}}$ & $3.88^{\mathrm{abc}}$ & $1.72^{\mathrm{a}}$ & $1.62^{\mathrm{a}}$ & $43.00^{\mathrm{i}}$ & $86.00 \mathrm{e}$ & $42.50^{\mathrm{m}}$ & $43.67^{\mathrm{mkl}}$ & $297.78^{c}$ & $96.67^{\mathrm{b}}$ & $12.2^{\mathrm{a}}$ & $11.2^{\text {6abcdef }}$ & $17.40^{\text {Imnopqr }}$ & $23.40^{\mathrm{ab}}$ \\
\hline NRCHB506 & $3.16^{\mathrm{bcd}}$ & $3.28^{\mathrm{bcd}}$ & $1.83^{\mathrm{a}}$ & $1.64^{\mathrm{a}}$ & $86.00^{\mathrm{e}}$ & $86.00 \mathrm{e}$ & $57.17^{\mathrm{a}}$ & $39.83^{\text {onp }}$ & $185.56^{\mathrm{n}}$ & $162.22^{\mathrm{t}}$ & $11.5^{\text {4abcd }}$ & $10.94^{\text {sabcdefgh }}$ & $17.87^{\mathrm{ijklmnopq}}$ & $18.15^{\mathrm{ijklmnop}}$ \\
\hline $\begin{array}{c}\text { Pusa Jai } \\
\text { kisan }\end{array}$ & $3.16 b^{\mathrm{cd}}$ & $3.17^{\mathrm{abcd}}$ & $1.56^{\mathrm{a}}$ & $1.67^{\mathrm{a}}$ & $57.33^{\mathrm{h}}$ & $71.67^{f}$ & $23.67^{\mathrm{vw}}$ & $35.17^{\mathrm{q}}$ & $163.33^{t}$ & $88.33^{\mathrm{e}}$ & $11.32 \mathrm{a}^{\mathrm{bcdef}}$ & $10.52^{\text {bcdefghijk }}$ & $14.02^{\mathrm{w}}$ & $14.51^{\mathrm{vw}}$ \\
\hline NDRE-7 & $3.04^{\mathrm{d}}$ & $3.4 \mathrm{~b}^{\mathrm{cd}}$ & $1.68^{\mathrm{a}}$ & $1.58^{\mathrm{a}}$ & $57.33^{\mathrm{h}}$ & $71.67^{\mathrm{f}}$ & $35.17^{\mathrm{q}}$ & $40.83^{\mathrm{n}}$ & $230.00^{\mathrm{i}}$ & $173.33^{r}$ & $11.39^{\text {abcde }}$ & $11.33^{\text {abcdef }}$ & $14.88^{\text {uvw }}$ & $17.52^{\mathrm{klmnopqr}}$ \\
\hline RL-1359 & $2.86^{\mathrm{bcd}}$ & $3.1^{\mathrm{bcd}}$ & $1.35^{\mathrm{a}}$ & $1.57^{\mathrm{a}}$ & $43.00^{\mathrm{i}}$ & $57.33^{\mathrm{h}}$ & $38.33^{\mathrm{p}}$ & $39.17^{\mathrm{qP}}$ & $202.22^{1}$ & $180.00^{\mathrm{p}}$ & $12.02^{\mathrm{ab}}$ & $11.1^{\text {abcdefg }}$ & $15.56^{\text {stuvw }}$ & $16.64^{\text {parst }}$ \\
\hline BEC-16 & $3.08^{\mathrm{bcd}}$ & $3.14^{\text {bcd }}$ & $1.73^{\mathrm{a}}$ & $1.92^{\mathrm{a}}$ & $43.00^{\mathrm{i}}$ & $86.00^{\mathrm{e}}$ & $38.50^{\text {op }}$ & $50.33 c^{d}$ & $276.67^{\mathrm{d}}$ & $243.33^{\mathrm{g}}$ & $8.93^{\mathrm{klmnopqr}}$ & $7.57^{\mathrm{rst}}$ & $18.18^{\mathrm{ijklmnop}}$ & $19.20^{\text {ghij }}$ \\
\hline
\end{tabular}

$\mathrm{T}$ comparison lines for least Squares means of genotypes*nitrogen

LS- means with same letters are not significantly different 


\section{Total antioxidant capacity}

Phenolic compounds and ascorbic acid are known for its antioxidant properties which are highly desirable for improving the keeping quality of meal as well as for providing health benefits. Seed meal extracts of 24 genotypes of Indian mustard showed TAC to range between $20 \mathrm{mg} / \mathrm{g} \mathrm{AAE}$ (HB-9916) to $48 \mathrm{mg} / \mathrm{g} \mathrm{AAE}$ (Rohini) under N0 and between $21.83 \mathrm{mg} / \mathrm{g}$ AAE (HB9912) to $54 \mathrm{mg} / \mathrm{g}$ AAE (EC399307) under N80 application (Table 1). We observed, $58 \%$ of genotypes showed TAC to increase and $42 \%$ of genotypes showed reduction in TAC over N0. It may be noted that the genotypes in which the TAC was lowered also showed concomitant reduction in ascorbic acid. According to Nguyen and Niemeyer (2008) reduction in TAC upon treatment with $\mathrm{NO}_{3}{ }^{-}$correlated with phenol content. Aires et al. (2011) examined the potential antioxidant activities of ascorbic acid, total flavanoid and total phenol in Brassica vegetables and concluded that among the naturally occurring antioxidants, ascorbic acid contributed the maximum towards antioxidant capacity. Our findings are in agreement with this. Ochoa-Velaso et al. (2016) have reported that TAC was strongly influenced by ascorbic acid and phenolic content in tomatoes. The correlation between TAC with that of phenols and ascorbic acid observed in our study $(\mathrm{r}=0.316, \mathrm{p}=0.028)$ is comparatively less but statistically significant (Table $2 a$ ).

Table 2a. Pearson Correlation between total antioxidant, vitamin $C$ and total phenol

\begin{tabular}{c|c|c|c|c}
\hline \multicolumn{5}{c}{$\begin{array}{c}\text { Pearson Correlation Coefficients, } \mathbf{N}=48 \\
\text { Prob> } \mathbf{r} \text { under H0: Rho=0 }\end{array}$} \\
\hline & $\begin{array}{c}\text { Total antioxidant } \\
\text { capacity }\end{array}$ & Phenol & $\begin{array}{c}\text { Ascorbic } \\
\text { acid }\end{array}$ & $\begin{array}{c}\text { Phenol+ } \\
\text { Ascorbic } \\
\text { acid }\end{array}$ \\
\hline $\begin{array}{c}\text { Total } \\
\text { antioxidant } \\
\text { capacity }\end{array}$ & 1.00000 & 0.36613 & 0.31511 & 0.31699 \\
Phenol & & 0.0105 & 0.0291 & 0.0281 \\
& 0.36613 & 1.00000 & 0.12944 & 0.13515 \\
Ascorbic acid & 0.0105 & 0.12944 & 0.3806 & 0.3597 \\
Phenol+ & 0.31511 & 0.3806 & 1.00000 & 0.99998 \\
Ascorbic acid & 0.0291 & 0.13515 & 0.99998 & $<.0001$ \\
\hline
\end{tabular}

Table $2 \boldsymbol{b}$. Pearson Correlation between total nitrogen and soluble protein

\begin{tabular}{l|c|c}
\hline \multicolumn{3}{c}{ Pearson Correlation Coefficients, $\mathbf{N}=48$} \\
\hline Prob $>|\mathbf{r}|$ under H0: Rho=0 \\
\hline protein & nitrogen & protein \\
& 1.00000 & 0.33743 \\
& & 0.0190 \\
\hline
\end{tabular}




\section{Soluble sugars}

Seed meal of $B$. juncea is comprised of about $30 \%$ carbohydrates which includes many beneficial as well as harmful components. One report showed soluble sugars such as stachyose and raffinose are harmful as it causes flatulence in animals and digestive problems in poultry (Hartwig et al., 1997). In this study, we evaluated the effect of N80 treatment on soluble sugar content. The total soluble sugar ranged between $74.44 \mathrm{mg} / \mathrm{g}$ (EC399300) to $546.71 \mathrm{mg} / \mathrm{g}$ (DHR-991) under N0. Under, N80 application it ranged from $60 \mathrm{mg} / \mathrm{g}$ (EC399307, HB9902) to $404 \mathrm{mg} / \mathrm{g}$ (DHR-991). All genotypes reported reduction in total soluble sugar level ranging from $8 \%$ (Maya) to $80 \%$ (HB-9912). Similar observations were made by Smolen and Sady (2009) in carrots (Daucus carota L.). Further, Krober and Cartter (1962) had shown reduction in soluble sugar content in four cultivars of soybean at higher nitrogen input with a concomitant increase in protein content. Higher nitrogen levels may divert the biosynthetic process as towards the amino acids and proteins consequently reducing the production of soluble carbohydrates. This may be true in $63 \%$ genotypes having inverse relationship between soluble sugars and seed nitrogen content. But, contrasting results was observed in $37 \%$ of genotypes where they experienced reduction in both parameters after N80 treatment.

\section{Cruder fiber}

Fiber is primarily derived from cell walls and is made up of cellulose, hemicelluloses and lignin. High fiber in animal's diet is undesirable as it would dilute the availability of energy, proteins and minerals such as Mn and Zn (Suprianto, 2014). As an animal feed, the seed meal should be preferably rich in protein and energy rich carbohydrates rather than crude fiber that only add to the bulk and cause digestive disorders. The crude fiber content in the genotypes under N0 ranged between $7.03 \%$ (Rohini) and $12.02 \%$ (RL-1359 and NRCDR-2) whereas; it ranged from $5.69 \%$ (DRMR-IJ-31) to $11.33 \%$ (NDRE-7) at N80 application (Table 1). $88 \%$ of the genotypes showed reduction in crude fiber content by $1.10 \%(\mathrm{GM}-2)$ to $35 \%$ (DRMR-IJ-31) over N0. One report is in agreement with decrease of crude fiber content in fodder beet but it is also dependent on the type of nitrogen fertilizer (Khogali et al., 2011). Within the same experiment they observed no significant effects in maize. Similarly, in forage kale no effect on fiber content was observed (Chakwizira et al., 2015). It is quite evident that response to nitrogen application is not the same in all crops. In the present experiments about $12 \%$ of genotypes showed increase in crude fiber content by $7 \%$ (Rohini, HB-207) to $17.9 \%$ (EC399294). This suggests that variations in seed nitrogen upon N80 application leads to variation in crude fiber and is genotype dependent.

\section{Total soluble protein and seed storage protein}

The two major seed storage proteins of oilseed Brassica are the $2 \mathrm{~S}$ albumin called napin and the $11 \mathrm{~S}$ or cruciferin a legume type globulin having heteromeric structure. Cruciferin, rich in nitrogen containing amino acids have role in modulating nitric oxide signaling which is potential regulator of nutrient metabolism (Wanasundara, 2011), while albumin rich in sulphur containing amino acids have been annotated with several allergic responses such as celiac disease and Baker's asthma (Wanasundara, 2011). However, not all 2S 
albumin causes allergy and it affects only a minority of the population (Wanasundara, 2011). None the less, both storage proteins have found its place in industry as they are highly surface active in monolayers and emulsion formation (Wanasundara, 2011).

Profiling of seed storage proteins with respect to nitrogen treatment has never been done in Indian mustard. We have profiled the seed storage proteins in 24 genotypes of $B$. juncea using SDS-PAGE to see the effect of nitrogen application on the protein profile (Fig. 1). Molecular weights of the proteins were compared to previous reports (Wanasundara, 2011, Wanasundara et al., 2012). Our results showed genotypes DRMR-IJ-31, HB-207, HB-9902, NATP-124, RGN-55, NRCHB-506 had low expression of 2S albumin in case of nitrogen treatment (Fig. 1). According to Wanasundara et al. (2012) molecular weight of cruciferin ranged between $18.1 \mathrm{kDa}$ and $31.2 \mathrm{kDa}$ in B.juncea and that of napin between 6.5 and 12 $\mathrm{kDa}$ in reducing environment. But we found the corresponding band between 15 and 16 $\mathrm{kDa}$ for napin. This difference in molecular weight may be due to the slight modification in the protocol as we had given heat treatment only for 4 min instead of 15 min as reported earlier. We found genotypic variability in the banding patterns of $\alpha$ and $\beta$ chains of cruceferin (Fig 1). According to Yu (2008) this determines the digestibility of proteins in $B$. rapa and $B$. napus. Since this is the first report in $B$. juncea, it will lead to better ideas on manipulating the meal composition for quality improvement by managing nitrogen fertilization.

\section{Application of nitrogen influences the nutritional quality of oil}

Nutritional composition of oil

There are reports on the effect of nitrogen fertilizer on improvement of oil yield and quality (Joshi et al., 1998; Paramar and Paramar, 2012) but, there are no sufficient data to support the role of nitrogen fertilizers in modifying the nutritional composition of oil in $B$. juncea genotypes. Fatty acid profiling in 24 genotypes was done under treated and controlled conditions (Table 3). Our results showed, SFA (Palmitic +Stearic acid) content to be within $1.37 \%(\mathrm{RGN}-55)$ to $5.76 \%$ (HB-9902) at N0 and between 1.96\% (HB-9916) to $4.32 \%$ (NDRE-7) under N80 (Table 3). About $50 \%$ of genotypes showed decrease in SFA and $50 \%$ showed increase compared to control, but the rise in SFA levels were still within the permissible limit $(<7 \%)$ of healthy edible oil. Paramar and Paramar (2012) have also found a significant decrease in SFA at $50 \mathrm{~kg} / \mathrm{ha}$. Reduction in SFA is desirable as it is associated with cardiovascular diseases. Even though, SFA content of Indian mustard is within the optimum range it is possible to manipulate its level by optimizing the nitrogen application as evident from our study.

The level of MUFA (Oleic + Eicosenoic + Erucic) ranged from 50.79\% (HB-9902) to $63.51 \%$ (NDRE-7) under N0 and from 54.16\% (NDRE-7) to $61.65 \%$ (NATP-124) under N80. The levels of MUFA were found to have increased in about $58 \%$ of genotypes by $1.02 \%$ (EC39900) to $20.46 \%$ (HB-9902) over N0, while in the rest $42 \%$ of genotypes it decreases by $0.27 \%(78-1-1-1)$ to $14.72 \%$ (NDRE-7) over control. 

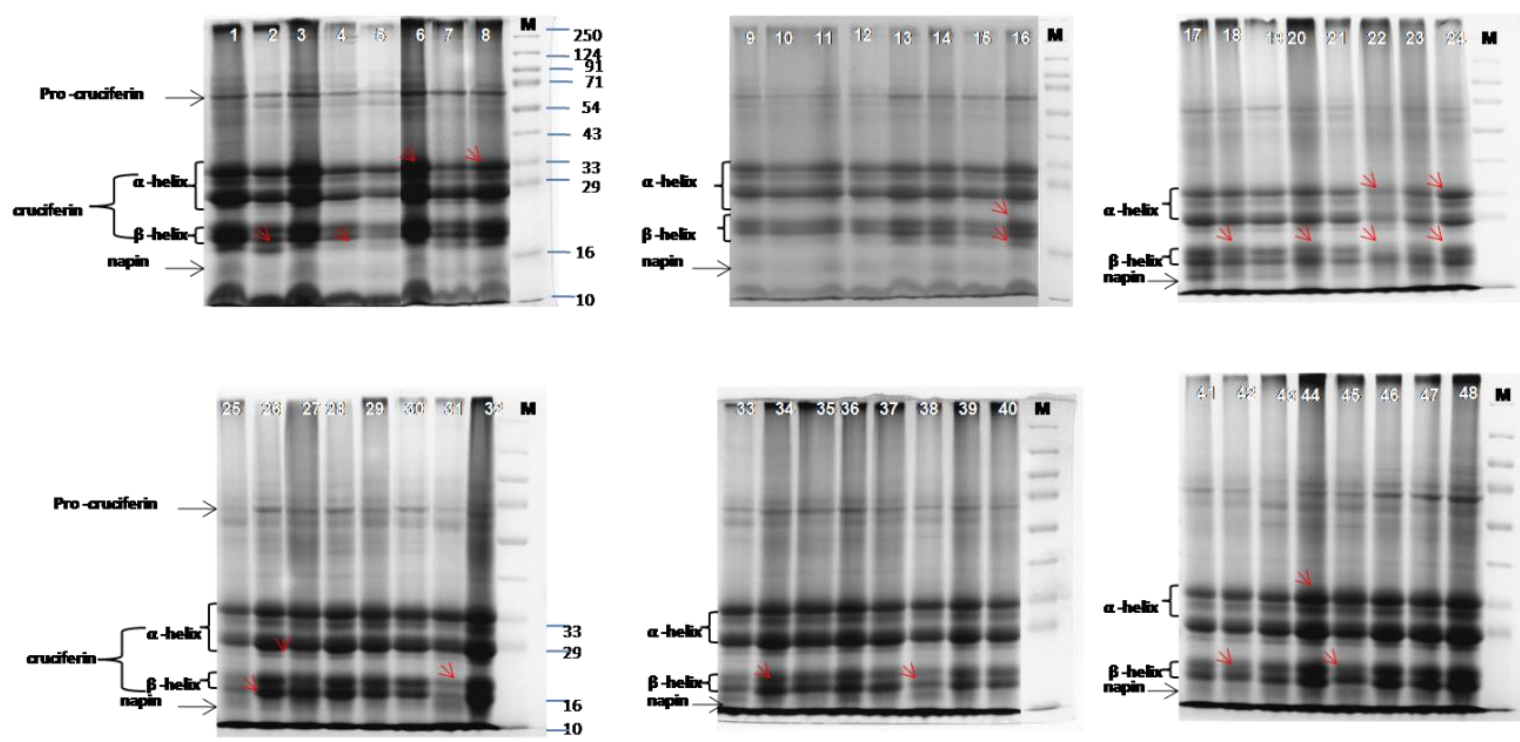

Figure 1. Seed storage protein profiling in 24 genotypes of Indian Musatrd under zero and 80kg/ha nitrogen application

Lane 1 and 2 : DRMR IJ-31 under control and 80kg N/ha; Lane 3 and 4 : Maya under control and 80kg N/ha; Lane 5 and 6: 78-1-1-1 under control and 80kg N/ha; Lane 7 and 8: DHR-991 under control and 80kg N/ha; Lane 9 and 10:GM-2 under control and 80kg N/ha; Lane11and12:EC-399307 under control and 80kg N/ha; Lane13and14: EC-399300 under control and 80kg N/ha; Lane 15and16: EC-399294 under control and 80kg N/ha Lane 17and18: Rohini under control and 80kg N/ha. Lane 19and20:HB-207 under control and 80kg N/ha; Lane 21and22:HB-9902 under control and 80kg N/ha; Lane 23and24: HB-9912 under control and 80kg N/ha; Lane 25and26:HB-9916 under control and 80kg N/ha; Lane 27and28:IC212031 under control and 80kg N/ha; Lane 29and30:NATP-124 under control and 80kg N/ha; Lane 31and32: QM-16 under control and 80kg N/ha; Lane 33and34: RGN-55 under control and 80kg N/ha; Lane 35and36: NRCHB-101 under control and 80kg N/ha; Lane 37and38: NRCDR-2 under control and 80kg N/ha; Lane 39and40: NRCHB-506 under control and 80kg N/ha; Lane 41and42:Pusajai kisan under control and 80kg N/ha; Lane 43and44: NDRE-7 under control and 80kg N/ha; Lane 45and46: RL-1359 under control and 80kg N/ha; Lane 47and48 BC-16: under control and $80 \mathrm{~kg} \mathrm{~N} / \mathrm{ha}$; Lane M: wide ranged protein ladder $(\mathrm{kDa})$. ( $\rightarrow$ indicates the change in $\alpha$ and $\beta$ banding pattern.

Mustard oil contains moderate levels of PUFA that includes linoleic acid and linolenic acid (15-20\%) which is ideal range for healthy oil. They are essential fatty acids and are required for the biosynthesis of eicosapentanoic acid and docosahexanoic acid, which are beneficial to human beings. In this study, linoleic acid (w6) ranged from $13.47 \%$ (DHR991) to $22.94 \%$ (HB-9002) under N0 and $15.20 \%$ (NRCHB-506) to $22.38 \%$ (QM-16) for N80. Since, almost all genotypes analyzed in this study are having $>15 \% \omega 6$ content, they can be used as potential source for extraction (Zambiazi et al., 2007). It is to be noted, about $42 \%$ of the genotypes showed increase in $\omega 6$ by $1.23 \%$ (NRCHB-101) to $29.32 \%$ (DHR-991) over N0. Whereas, $58 \%$ of the genotypes showed reduction in $\omega 6$ by $0.89 \%$ (EC399300) to $18.20 \%$ (HB-9916) over N0 application. 
Table 3. Fatty acid profile of 24 genotypes of B. juncea at NO and N80 application

\begin{tabular}{|c|c|c|c|c|c|c|c|c|c|c|c|c|}
\hline Samples & $\begin{array}{c}\text { Palmitic } \\
(\%)\end{array}$ & $\begin{array}{c}\text { Stearic } \\
(\%)\end{array}$ & $\begin{array}{c}\text { Oleic } \\
(\%)\end{array}$ & $\begin{array}{c}\text { Linoleic } \\
(\%)\end{array}$ & $\begin{array}{c}\text { Linolenic } \\
(\%)\end{array}$ & $\begin{array}{c}\text { Eicosenoic } \\
(\%)\end{array}$ & $\begin{array}{c}\text { Erucic } \\
(\%)\end{array}$ & $\omega 6 / \omega 3$ & $\begin{array}{l}\text { SFA } \\
(\%)\end{array}$ & $\begin{array}{c}\text { MUFA } \\
(\%)\end{array}$ & $\begin{array}{c}\text { PUFA } \\
(\%)\end{array}$ & MUFA:PUFA \\
\hline $\begin{array}{c}\text { DRMRIJ-31 } \\
\left(\mathrm{N}_{0}\right)\end{array}$ & $2.83^{\text {fghijklmn }}$ & $0.17^{\mathrm{qrst}}$ & $7.86^{\mathrm{t}}$ & $18.7^{\text {at }}$ & $19.56^{\mathrm{f}}$ & $15.42^{\mathrm{d}}$ & $35.15^{\mathrm{x}}$ & $0.956^{\text {uvts }}$ & $3^{\mathrm{k}}$ & $58.43^{\mathrm{s}}$ & $38.26^{\text {fghijklmn }}$ & $1.53^{\text {bcdefghi }}$ \\
\hline $\begin{array}{c}\text { DRMRIJ-31 } \\
\left(\mathbf{N}_{80}\right)\end{array}$ & $2.67^{\text {fghijklmn }}$ & $0.22^{\mathrm{pqr}}$ & $8.04^{\mathrm{s}}$ & $17.97^{\mathrm{yx}}$ & $20.36^{\mathrm{c}}$ & $15.29^{\mathrm{e}}$ & $34.75^{z}$ & 0.883 & $2.89^{\mathrm{k}}$ & $58.08^{\mathrm{t}}$ & $38.33^{\text {fghijklmn }}$ & $1.52^{\text {abcdefg }}$ \\
\hline $\begin{array}{c}\text { Maya } \\
\left(\mathbf{N}_{0}\right)\end{array}$ & $3.44^{\text {abcdef }}$ & $0.53^{\mathrm{bcd}}$ & $9.99^{\mathrm{f}}$ & $20.1^{\mathrm{lk}}$ & $17.94^{\mathrm{q}}$ & $13.26^{1}$ & $34.11^{\mathrm{b}}$ & $1.120^{\mathrm{ijk} k \mathrm{lmn}}$ & $3.97^{\mathrm{no}}$ & $57.36^{\mathrm{w}}$ & $38.04^{\text {bcdefg }}$ & $1.51^{\text {bcdefghi }}$ \\
\hline $\begin{array}{c}\text { Maya } \\
\left(\mathbf{N}_{80}\right)\end{array}$ & $2.06_{\mathrm{r}}^{\mathrm{j} k \mathrm{lmnopq}}$ & $\underset{n}{0.38^{\text {hijklm }}}$ & $8.72^{\mathrm{n}}$ & $17.87^{\mathrm{z}}$ & $17.93^{\mathrm{q}}$ & $12.2^{\mathrm{u}}$ & $39.56^{\mathrm{n}}$ & $0.997^{\text {qrstu }}$ & $2.44^{\mathrm{x}}$ & $60.48^{\text {iw }}$ & $35.8^{\mathrm{mnopqr}}$ & $1.69^{\text {abcdefg }}$ \\
\hline $\begin{array}{c}\text { 78-1-1-1 } \\
\left(\mathrm{N}_{0}\right)\end{array}$ & $2.32^{\mathrm{ijk} l m n o p}$ & $0.24^{\mathrm{pqr}}$ & $10.07^{\mathrm{f}}$ & $20.92^{\mathrm{g}}$ & $19.17^{\mathrm{i}}$ & $14.34^{\mathrm{j}}$ & $31.75^{\mathrm{f}}$ & $1.091^{\mathrm{jklmnop}}$ & $2.56^{\mathrm{g}}$ & $56.16^{\mathrm{x}}$ & $40.09^{\mathrm{ijklmnopq}}$ & $1.40^{\mathrm{fghi}}$ \\
\hline $\begin{array}{c}78-1-1-1 \\
\left(N_{80}\right)\end{array}$ & $3.5^{\text {bcdef }}$ & $0.21^{\mathrm{qrs}}$ & $6.69^{\mathrm{z}}$ & $20.54^{\mathrm{i}}$ & $17.8^{\mathrm{r}}$ & $12.8^{\mathrm{qp}}$ & $36.52^{\mathrm{u}}$ & $1.154^{\text {ghijk }}$ & $3.71^{\mathrm{k}}$ & $56.01^{\mathrm{y}}$ & $38.34^{\text {bcdef }}$ & $1.46^{\text {bcdefghi }}$ \\
\hline $\begin{array}{c}\text { DHR-991 } \\
\left(\mathrm{N}_{0}\right)\end{array}$ & $2.14^{\operatorname{lmnopq}}$ & $\begin{array}{c}0.41_{\mathrm{m}}^{\text {fghijkl }} \\
\text { 势 }\end{array}$ & $6.83^{y}$ & $13.47^{\mathrm{g}}$ & $13.61^{\mathrm{i}}$ & $12.99^{n}$ & $39.64^{\mathrm{nm}}$ & $0.990^{\text {qrstu }}$ & $2.55^{\mathrm{k}}$ & $59.46^{\mathrm{no}}$ & $27.08^{\operatorname{lmnopq}}$ & $2.20^{\mathrm{a}}$ \\
\hline DHR-991 $\left(\mathbf{N}_{80}\right)$ & $3.52^{\text {bcdef }}$ & 0.58 & $8.42^{\mathrm{p}}$ & $17.42^{\mathrm{b}}$ & $17.39^{\mathrm{t}}$ & $12.01^{\mathrm{v}}$ & $40.03^{\mathrm{k}}$ & $1.002^{\mathrm{qrst}}$ & $4.1^{\mathrm{c}}$ & $60.46^{\mathrm{i}}$ & $34.81^{\text {bcdef }}$ & $1.74^{\text {bcdefghi }}$ \\
\hline $\operatorname{EC399294}\left(\mathrm{N}_{0}\right)$ & $3.58^{\text {bcdef }}$ & $0.48^{\text {defg }}$ & $9.97^{\mathrm{f}}$ & $18.83^{\mathrm{s}}$ & $16.97^{\mathrm{w}}$ & $11.85^{\mathrm{wx}}$ & $37.63^{\mathrm{q}}$ & $1.110^{\mathrm{ijklmno}}$ & $4.06^{\mathrm{x}}$ & $59.45^{\circ}$ & $35.8^{\text {bcdef }}$ & $1.66^{\text {bcdefghi }}$ \\
\hline $\begin{array}{c}\text { EC399294 } \\
\left(\mathbf{N}_{80}\right)\end{array}$ & 2.29 & $0.33^{\mathrm{omn}}$ & $8.36^{\mathrm{p}}$ & $16.06^{\mathrm{b}}$ & $15.97^{\mathrm{az}}$ & $10.75^{\mathrm{c}}$ & $41.1^{\mathrm{g}}$ & $1.006^{\mathrm{pqrst}}$ & $2.62^{\mathrm{g}}$ & $60.21 \mathrm{j}$ & $32.03^{\mathrm{jklmnop}}$ & $1.88^{\text {bcdef }}$ \\
\hline $\operatorname{EC399300}\left(\mathrm{N}_{0}\right)$ & $3.41^{\text {bcdefg }}$ & $0.35^{\mathrm{klmn}}$ & $9.78^{\mathrm{g}}$ & $22.36^{\mathrm{c}}$ & $18.45^{\mathrm{nm}}$ & $14.93^{\mathrm{g}}$ & $30.38^{\mathrm{j}}$ & $1.212^{\mathrm{defgh}}$ & $3.76^{\mathrm{e}}$ & $55.09^{\mathrm{dc}}$ & $40.81^{\text {bcdefg }}$ & $1.35^{\mathrm{hi}}$ \\
\hline $\begin{array}{c}\text { EC399300 } \\
\left(\mathbf{N}_{80}\right)\end{array}$ & $3.02^{\text {defghijkl }}$ & $0.48^{\text {dgef }}$ & $\underset{\mathrm{c}}{11.26}$ & $22.16^{\mathrm{d}}$ & $17.79^{r}$ & $12.88^{\mathrm{op}}$ & $31.51^{\mathrm{g}}$ & $1.246^{\text {cdef }}$ & $3.5^{\mathrm{h}}$ & $55.65^{\mathrm{a}}$ & $39.95^{\text {defhgijklm }}$ & $1.39^{\text {bcdefghi }}$ \\
\hline $\operatorname{EC399307}\left(\mathbf{N}_{0}\right)$ & $3.79^{\text {bcde }}$ & $0.46^{\text {defgh }}$ & $9.11^{\mathrm{v}}$ & $19.61^{\mathrm{p}}$ & $16.73^{x}$ & $13.18^{\mathrm{ml}}$ & $36.46^{\mathrm{u}}$ & $1.172^{\text {efghij }}$ & $4.25^{\mathrm{v}}$ & $58.75^{\mathrm{r}}$ & $36.34^{\text {bcde }}$ & $1.62^{\text {bcdefghi }}$ \\
\hline $\begin{array}{c}\mathbf{E C 3 9 9 3 0 7} \\
\left(\mathbf{N}_{80}\right)\end{array}$ & $\begin{array}{c}2.97_{\mathrm{mn}}^{\mathrm{defghijk} \mathrm{l}} \\
\end{array}$ & $0.4^{\text {ghijklm }}$ & $7.8^{\mathrm{tu}}$ & $17.61^{\mathrm{a}}$ & $15.49^{\mathrm{e}}$ & $11.28^{\mathrm{a}}$ & $43.25^{\mathrm{d}}$ & $1.137^{\text {hijklm }}$ & $3.37^{\mathrm{f}}$ & $62.33^{\mathrm{c}}$ & $33.1^{\text {defghijklm }}$ & $1.88^{\mathrm{abcdef}}$ \\
\hline GM-2 $\left(\mathbf{N}_{0}\right)$ & $\begin{array}{c}2.97^{\text {defghijkk }} \\
\mathrm{lm}\end{array}$ & $0.13^{\mathrm{ts}}$ & $6.48^{\mathrm{ao}}$ & $18.04^{x}$ & $19.34^{\mathrm{h}}$ & $11.94^{\mathrm{v}}$ & $41.14^{\mathrm{gf}}$ & 0.933 & $3.1^{\mathrm{t}}$ & $59.56^{\mathrm{m}}$ & $37.38^{\text {defghijklm }}$ & $1.59^{\text {bcdefghi }}$ \\
\hline
\end{tabular}




\begin{tabular}{|c|c|c|c|c|c|c|c|c|c|c|c|c|}
\hline GM-2 $\left(\mathbf{N}_{80}\right)$ & $1.89^{\text {nopqr }}$ & $0.34^{\operatorname{lmn}}$ & $8.56^{\mathrm{j}}$ & $21.47^{\mathrm{e}}$ & $15.66^{\mathrm{c}}$ & $7.93^{\mathrm{i}}$ & $43.74^{\mathrm{c}}$ & $1.371^{\mathrm{ba}}$ & $2.23^{\mathrm{u}}$ & $60.23^{\mathrm{kj}}$ & $37.13^{\text {nopqr }}$ & $1.62^{\text {abcdefgh }}$ \\
\hline $\operatorname{Rohini}\left(\mathbf{N}_{0}\right)$ & $1.95^{\text {nopqr }}$ & $0.19^{\mathrm{qrst}}$ & $7.52^{w}$ & $18.34^{\mathrm{v}}$ & $19.76^{\mathrm{d}}$ & $12.12^{\mathrm{u}}$ & $39.7^{1 \mathrm{~m}}$ & $0.928^{\text {tuv }}$ & $2.14^{\mathrm{nm}}$ & $59.35^{\mathrm{p}}$ & $38.1^{\text {nopqr }}$ & $1.56^{\mathrm{bcdefgh}}$ \\
\hline $\operatorname{Rohini}\left(\mathbf{N}_{80}\right)$ & $3.1^{\text {defghijk }}$ & $0.25^{\mathrm{opq}}$ & $9.47^{\mathrm{j}}$ & $19.73^{\circ}$ & $15.57^{\mathrm{de}}$ & $14.57^{\mathrm{i}}$ & $37.23^{\mathrm{r}}$ & $1.267^{\mathrm{cd}}$ & $3.35^{\mathrm{z}}$ & $61.27^{\mathrm{f}}$ & $35.3^{\text {defghijk }}$ & $1.74^{\text {bcdefgh }}$ \\
\hline $\begin{array}{c}\text { HB-207 } \\
\left(\mathrm{N}_{0}\right)\end{array}$ & $2.84_{\mathrm{n}}^{\mathrm{efghijklm}}$ & $0.22^{\mathrm{pqr}}$ & $9.66^{\text {ih }}$ & 20.86 & $19.81^{\mathrm{d}}$ & $13.16^{\mathrm{m}}$ & $32.28^{\mathrm{e}}$ & $1.053^{\mathrm{nmopq}}$ & $3.06^{\mathrm{f}}$ & $55.1^{\mathrm{c}}$ & $40.67^{\text {efghijklmn }}$ & $1.35^{\text {efghi }}$ \\
\hline $\begin{array}{c}\text { HB-207 } \\
\left(\mathbf{N}_{80}\right)\end{array}$ & $2.17^{\mathrm{klmnop}}$ & $0.49^{\text {cdef }}$ & $\underset{\mathrm{e}}{10.41}$ & $19.83^{\mathrm{n}}$ & $15.06^{\mathrm{g}}$ & $11.51^{\mathrm{z}}$ & $40.2^{\mathrm{j}}$ & $1.317^{\mathrm{bc}}$ & $2.66 \mathrm{~b}$ & $62.12^{\mathrm{d}}$ & $34.89^{\mathrm{klmnop}}$ & $1.78^{\text {bcdefgh }}$ \\
\hline $\begin{array}{c}\text { HB-9902 } \\
\left(\mathrm{N}_{0}\right)\end{array}$ & $4.8^{\mathrm{a}}$ & $0.96^{\mathrm{a}}$ & $\underset{\mathrm{a}}{11.87}$ & 22.94 & $18.38^{\text {npo }}$ & $9.16^{\mathrm{f}}$ & $29.76^{\mathrm{k}}$ & $1.248^{\text {cdef }}$ & $5.76^{\mathrm{c}}$ & $50.79^{\mathrm{i}}$ & $41.32^{\mathrm{a}}$ & $1.23^{\mathrm{i}}$ \\
\hline $\begin{array}{c}\text { HB-9902 } \\
\left(\mathbf{N}_{80}\right)\end{array}$ & $\begin{array}{c}2.43^{\text {hijklmno }} \\
\text { p }\end{array}$ & $0.53^{\mathrm{bcd}}$ & $8.23^{q}$ & $19.65^{\text {po }}$ & $16.02^{\mathrm{z}}$ & $11.79^{\mathrm{yx}}$ & $41.16^{\mathrm{gf}}$ & $1.227^{\mathrm{defg}}$ & $2.96^{\text {poy }}$ & $61.18^{\mathrm{g}}$ & $35.67^{\text {hijklmnop }}$ & $1.72^{\text {abcdefgh }}$ \\
\hline $\begin{array}{c}\text { HB-9912 } \\
\left(\mathrm{N}_{0}\right)\end{array}$ & $4.14^{\mathrm{ab}}$ & $0.42_{\mathrm{kl}}^{\text {efghij }}$ & $10.4^{\mathrm{d}}$ & $20.18^{\mathrm{k}}$ & $19.05^{\mathrm{j}}$ & $15.13^{\mathrm{f}}$ & $29.8^{\mathrm{k}}$ & $1.0591^{\mathrm{mnopq}}$ & $4.56^{\mathrm{i}}$ & $55.87^{\mathrm{z}}$ & $39.23^{\mathrm{ba}}$ & $1.42^{\text {cdefgh }}$ \\
\hline $\begin{array}{c}\text { HB-9912 } \\
\left(\mathrm{N}_{80}\right)\end{array}$ & $3.51^{\text {bcdef }}$ & $0.5^{\text {bdeg }}$ & $9.7^{\mathrm{hg}}$ & $19.62^{\mathrm{p}}$ & $18.36^{\mathrm{po}}$ & $11.71^{\mathrm{y}}$ & $36^{\mathrm{w}}$ & $1.069^{\mathrm{klmnopq}}$ & $4.01^{\mathrm{ef}}$ & $57.41^{\mathrm{w}}$ & $37.98^{\text {bcdef }}$ & $1.51 \mathrm{a}^{\mathrm{bcdefgh}}$ \\
\hline $\begin{array}{c}\text { HB-9916 } \\
\left(\mathrm{N}_{0}\right)\end{array}$ & $3.23^{\text {bcdefghij }}$ & $0.53^{\mathrm{bcd}}$ & $9.14^{\mathrm{e}}$ & $19.23^{\mathrm{r}}$ & $16.12^{y}$ & $12.75^{\mathrm{qr}}$ & $38.96^{\mathrm{p}}$ & $1.193^{\text {defghi }}$ & $3.76^{\mathrm{z}}$ & $60.85^{\mathrm{h}}$ & $35.35^{\text {bcdefgh }}$ & $1.72^{\text {abcdefg }}$ \\
\hline $\begin{array}{c}\text { HB-9916 } \\
\left(\mathrm{N}_{80}\right)\end{array}$ & $1.6^{\mathrm{pqor}}$ & $0.36^{\mathrm{jklmn}}$ & $7.74^{\mathrm{uv}}$ & $15.73^{\mathrm{e}}$ & $13.31^{\mathrm{j}}$ & $11.24^{\mathrm{a}}$ & $41.21^{\mathrm{f}}$ & $1.182^{\text {defghi }}$ & $1.96^{\mathrm{j}}$ & $60.19^{\mathrm{k}}$ & $29.04^{\text {pqor }}$ & $2.07^{\mathrm{abcd}}$ \\
\hline $\operatorname{IC212031}\left(\mathrm{N}_{0}\right)$ & $3.07^{\mathrm{defhijkl}}$ & $0.37^{\mathrm{ijk} \mathrm{kmn}}$ & $9.08^{1}$ & $19.42^{\mathrm{q}}$ & $18.48^{\mathrm{m}}$ & $14.12^{\mathrm{k}}$ & $35.28^{\mathrm{x}}$ & $1.051^{\mathrm{mnopq}}$ & $3.44^{\mathrm{pq}}$ & $58.48^{\mathrm{s}}$ & $37.9^{\text {cdefghijk }}$ & $1.54^{\text {bcdefghi }}$ \\
\hline $\operatorname{IC212031}\left(\mathrm{N}_{80}\right)$ & $3.13^{\text {efghid }}$ & $0.3^{\text {nop }}$ & $8.89^{\mathrm{m}}$ & $20.64^{\mathrm{h}}$ & $20.49^{\mathrm{b}}$ & $15.83^{\mathrm{c}}$ & $30.55^{\mathrm{i}}$ & $1.007^{\mathrm{pqrst}}$ & $3.43^{\mathrm{p}}$ & $55.27^{\mathrm{b}}$ & $41.13^{\text {defgh }}$ & $1.34^{\mathrm{defghi}}$ \\
\hline NATP-124 $\left(\mathbf{N}_{0}\right)$ & $\begin{array}{c}2.93_{\mathrm{m}}^{\text {cdefghijk }} \\
\text { the }\end{array}$ & $0.11^{\mathrm{t}}$ & $7.79^{\text {ut }}$ & $18.71^{\mathrm{t}}$ & $19.47^{\mathrm{g}}$ & $12.7^{\mathrm{sr}}$ & $37.22^{\mathrm{r}}$ & $0.961^{\text {rstuv }}$ & $3.041^{\mathrm{m}}$ & $57.71^{\mathrm{u}}$ & $38.18^{\text {defghhijklm }}$ & $1.51^{\mathrm{abcdefghi}}$ \\
\hline $\begin{array}{c}\text { NATP-124 } \\
\left(\mathbf{N}_{80}\right)\end{array}$ & $3.18^{\text {defghi }}$ & $0.36^{\mathrm{jklmn}}$ & $6.98^{x}$ & $17.60^{\mathrm{a}}$ & $17.08^{\mathrm{v}}$ & $10.24^{\mathrm{d}}$ & $44.43^{\mathrm{a}}$ & $1.030^{\mathrm{opqrs}}$ & $3.54^{\mathrm{p}}$ & $61.65^{\mathrm{e}}$ & $34.68^{\text {defghij }}$ & $1.7^{8 \mathrm{abc}}$ \\
\hline QM-16 $\left(\mathrm{N}_{0}\right)$ & $2.75^{\text {fghijklmn }}$ & $0.44^{\text {jefghi }}$ & $\underset{\mathrm{d}}{10.95}$ & $22.70^{\mathrm{b}}$ & $18.48^{\mathrm{m}}$ & $12.8^{\mathrm{qp}}$ & $31.26^{\mathrm{h}}$ & $1.228^{\mathrm{bfge}}$ & $3.19^{\mathrm{d}}$ & $55.01^{\mathrm{pe}}$ & $41.18^{\text {fghijklmn }}$ & $1.34^{\mathrm{efghi}}$ \\
\hline QM-16 $\left(\mathbf{N}_{80}\right)$ & $3.42^{\text {bcdefg }}$ & $\underset{\mathrm{m}}{0.40^{\mathrm{ghijk}}}$ & $\underset{\mathrm{e}}{10.49}$ & $22.38^{\mathrm{c}}$ & $19.65^{\mathrm{e}}$ & $14.78^{\mathrm{h}}$ & $28.26^{1}$ & $1.139^{\mathrm{hijk} l}$ & $3.82^{\mathrm{b}}$ & $53.53^{\mathrm{h}}$ & $42.03^{\text {bcdefg }}$ & $1.27^{\text {bcdefghi }}$ \\
\hline
\end{tabular}




\begin{tabular}{|c|c|c|c|c|c|c|c|c|c|c|c|c|}
\hline RGN-55(N $\left(N_{0}\right)$ & $1.21^{\mathrm{qr}}$ & $0.16^{\mathrm{rts}}$ & $6.22^{\mathrm{b}}$ & $21.04^{\mathrm{f}}$ & $22.61^{\mathrm{a}}$ & $17.3^{\mathrm{a}}$ & $31.44^{\mathrm{g}}$ & $0.931^{\text {tuv }}$ & $1.37^{\mathrm{a}}$ & $54.96^{\mathrm{e}}$ & $43.65^{\mathrm{qr}}$ & $1.26^{\text {efghi }}$ \\
\hline RGN-55 $\left(\mathbf{N}_{80}\right)$ & $3.61^{\text {bcdef }}$ & $0.46^{\text {defgh }}$ & $8.18^{\mathrm{q}}$ & $20.041^{\mathrm{m}}$ & $15.93^{\mathrm{a}}$ & $11.05^{\mathrm{b}}$ & $40.31^{\mathrm{i}}$ & $1.258^{\mathrm{dc}}$ & $4.07^{w}$ & $59.54^{\mathrm{nm}}$ & $35.97^{\text {bcdef }}$ & $1.66^{\text {efghi }}$ \\
\hline $\begin{array}{c}\text { NRCHB-101 } \\
\left(\mathbf{N}_{0}\right)\end{array}$ & $\begin{array}{c}2.54^{\text {ghijklmn }} \\
\text { o }\end{array}$ & $\begin{array}{c}0.42^{\text {efghij }} \\
\mathrm{kl}\end{array}$ & $9.5^{\mathrm{j}}$ & $17.92^{z y}$ & $19.44^{\mathrm{g}}$ & $14.07^{\mathrm{k}}$ & $34.84^{\mathrm{z}}$ & $0.922^{\text {tuv }}$ & $2.96^{\mathrm{t}}$ & $58.41^{\mathrm{s}}$ & $37.36^{\text {ghijklmno }}$ & $1.56^{\text {bcdefghi }}$ \\
\hline $\begin{array}{c}\text { NRCHB-101 } \\
\left(\mathbf{N}_{80}\right)\end{array}$ & $3.24^{\text {bcdefghij }}$ & 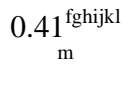 & $8.12^{\mathrm{sr}}$ & $18.14^{\mathrm{w}}$ & $17.73^{r}$ & $12.89^{\mathrm{op}}$ & $39.28^{\circ}$ & $1.023^{\mathrm{opqrs}}$ & $3.65^{\mathrm{x}}$ & $60.29^{j}$ & $35.87^{\text {bcdefghi }}$ & $1.68^{\text {bcdefgh }}$ \\
\hline $\begin{array}{c}\text { NRCDR-2 } \\
\left(\mathbf{N}_{0}\right)\end{array}$ & $1.52^{\mathrm{pqr}}$ & $0.45^{\text {defghi }}$ & $\underset{\mathrm{b}}{11.38}$ & $18.34^{\mathrm{v}}$ & $15.63^{\mathrm{dc}}$ & $8.87^{\mathrm{g}}$ & $43.77^{\mathrm{cb}}$ & $1.173^{\text {efghij }}$ & $1.97^{\mathrm{e}}$ & $64.02^{\mathrm{a}}$ & $33.97^{\mathrm{poq}}$ & $1.88^{\mathrm{ab}}$ \\
\hline $\begin{array}{c}\text { NRCDR-2 } \\
\left(\mathbf{N}_{80}\right)\end{array}$ & $3.88^{\mathrm{abcd}}$ & $0.4^{\text {ahijklm }}$ & 11.32 & $20.42^{\mathrm{j}}$ & $17.46^{\mathrm{ts}}$ & $12.33^{\mathrm{t}}$ & $33.9^{c}$ & $1.170^{\text {fghij }}$ & $4.28^{\mathrm{q}}$ & $57.55^{\mathrm{v}}$ & $37.88^{\mathrm{abcd}}$ & $1.52^{\text {bcdefgh }}$ \\
\hline $\begin{array}{c}\text { NRCHB506 } \\
\left(\mathrm{N}_{0}\right)\end{array}$ & $4.13^{\mathrm{abc}}$ & $0.98^{\mathrm{a}}$ & $9.5^{1 \mathrm{j}}$ & $15.20^{\mathrm{f}}$ & $15.83^{\mathrm{b}}$ & $12.62^{\mathrm{s}}$ & $37.09^{\mathrm{s}}$ & $0.960^{\text {stuv }}$ & $5.11^{\mathrm{h}}$ & $59.22^{\mathrm{q}}$ & $31.03^{\mathrm{abc}}$ & $1.91^{\text {abcdef }}$ \\
\hline $\begin{array}{c}\text { NRCHB506 } \\
\left(\mathbf{N}_{80}\right)\end{array}$ & $\underbrace{1.7^{\text {defghijklm }}}_{\text {nopqr }}$ & $0.57^{\mathrm{b}}$ & $7.49^{w}$ & $15.74^{\mathrm{e}}$ & $15.16^{\mathrm{f}}$ & $10.77^{\mathrm{c}}$ & $36.52^{\mathrm{u}}$ & $1.038^{\text {nopqrs }}$ & $2.27^{\mathrm{i}}$ & $54.78^{\mathrm{f}}$ & $30.9^{\text {opqr }}$ & $1.77^{\text {abcdef }}$ \\
\hline $\begin{array}{c}\text { Pusa Jai kisan } \\
\left(\mathbf{N}_{0}\right)\end{array}$ & $2.93^{\text {defghijk }}$ & $0.23^{\mathrm{pqr}}$ & $8.57^{\circ}$ & $19.99^{\mathrm{m}}$ & $18.96^{\mathrm{k}}$ & $14.36^{\mathrm{j}}$ & $34.48^{\mathrm{a}}$ & $1.054^{\mathrm{klmnopq}}$ & $3.16^{\mathrm{j}}$ & $57.41^{\mathrm{w}}$ & $38.95^{\text {bcdefghijklm }}$ & $1.4^{7 \mathrm{hig}}$ \\
\hline $\begin{array}{c}\text { Pusa Jai kisan } \\
\left(\mathrm{N}_{\mathbf{8 0}}\right)\end{array}$ & $3.37^{\text {bcdefghq }}$ & $0.47^{\text {defg }}$ & $7.74^{\mathrm{uv}}$ & $18.75^{\text {ts }}$ & $17.53^{\mathrm{s}}$ & $11.49^{\mathrm{z}}$ & $40.52^{\mathrm{h}}$ & $1.070^{\mathrm{klmnopq}}$ & $3.84^{\mathrm{v}}$ & $59.75^{1}$ & $36.28^{\text {dbcdefgh }}$ & $1.65^{\text {bcdefghi }}$ \\
\hline $\begin{array}{c}\text { NDRE-7 } \\
\left(\mathbf{N}_{0}\right)\end{array}$ & $1.18^{\mathrm{r}}$ & $0.23^{\mathrm{pqr}}$ & $6.45^{\mathrm{a}}$ & $16.69^{c}$ & $18.35^{\mathrm{p}}$ & $13.22^{\mathrm{ml}}$ & $43.84^{\mathrm{b}}$ & $0.91^{\mathrm{uv}}$ & $1.41^{\mathrm{a}}$ & $63.51^{\mathrm{b}}$ & $35.04^{\mathrm{R}}$ & $1.81^{\text {bcdefg }}$ \\
\hline $\begin{array}{c}\text { NDRE-7 } \\
\left(\mathbf{N}_{80}\right)\end{array}$ & $3.34^{\text {bcdefgh }}$ & $0.98^{\mathrm{a}}$ & $9.47^{\mathrm{j}}$ & $20.37^{\mathrm{j}}$ & $14.24^{\mathrm{h}}$ & $8.45^{\mathrm{h}}$ & $36.24^{\mathrm{v}}$ & $1.430^{\mathrm{a}}$ & $4.32^{\mathrm{d}}$ & $54.16^{\mathrm{g}}$ & $34.61^{\text {bcdefgh }}$ & $1.56^{\text {bcdefg }}$ \\
\hline $\begin{array}{c}\text { RL-1359 } \\
\left(\mathrm{N}_{0}\right)\end{array}$ & $3.25^{\text {bcdefghi }}$ & $0.13^{\mathrm{ts}}$ & $7.64^{v}$ & $17.69^{\mathrm{a}}$ & $17.25^{\mathrm{u}}$ & $11.94^{\mathrm{wv}}$ & $42.07^{\mathrm{e}}$ & $1.026^{\mathrm{opqrs}}$ & $3.38^{b}$ & $61.65^{\mathrm{e}}$ & $34.94^{\text {bcdefgh }}$ & $1.76^{\text {abcde }}$ \\
\hline $\begin{array}{c}\text { RL-1359 } \\
\left(\mathbf{N}_{80}\right)\end{array}$ & $3.62^{\text {bcdef }}$ & $\begin{array}{c}0.43^{\text {efghij }} \\
\text { k }\end{array}$ & $8.84^{\mathrm{m}}$ & $18.46^{\mathrm{u}}$ & $18.59^{1}$ & $12.9^{\text {on }}$ & $36.72^{t}$ & $0.993^{\text {qrstu }}$ & $4.05^{\mathrm{u}}$ & $58.46^{\mathrm{s}}$ & $37.05^{\mathrm{fbec}}$ & $1.58^{\text {abcdefgh }}$ \\
\hline BEC-16 $\left(\mathbf{N}_{0}\right)$ & $2.7^{\text {fghijklmn }}$ & $\begin{array}{c}0.38^{\text {hijklm }} \\
\text { n }\end{array}$ & $9.56^{\mathrm{ij}}$ & $18.16^{\mathrm{w}}$ & $19.44^{\mathrm{g}}$ & $9.91^{\mathrm{e}}$ & $39.81^{1}$ & $0.934^{\mathrm{uvt}}$ & $3.08^{\mathrm{s}}$ & $59.28^{q p}$ & $37.6^{\text {fghijklm }}$ & $1.58^{\text {bcdefg }}$ \\
\hline $\operatorname{BEC-16}\left(\mathrm{N}_{80}\right)$ & $3.37^{\text {bcdefgh }}$ & $0.4^{\text {ghijklm }}$ & $9.26^{\mathrm{k}}$ & $19.32^{\mathrm{r}}$ & $18.44^{\mathrm{nmo}}$ & $15.95^{\mathrm{b}}$ & $33.22^{\mathrm{d}}$ & $1.048^{\text {nopqr }}$ & $3.77^{\mathrm{r}}$ & $58.43^{\mathrm{s}}$ & $37.76^{\text {bcdefg }}$ & $1.55^{\text {bcdefg }}$ \\
\hline
\end{tabular}

$\mathrm{T}$ comparison lines for least Squares means of genotypes*nitrogen

LS- means with same letters are not significantly different 
The $\omega 3$ levels were found to range between $13.62 \%$ (DHR-991) and $22.61 \%$ (RGN-55) under N0 while, under N80 it ranged between 13.31\% (HB-9916) to 20.49\% (IC212031). These levels are high enough $(>12 \%)$ to be considered as a source for commercial extraction of $\omega 3$ according to Zambiazi et al. (2007) who reported the bench mark to be 12 $\%$. It has been reported earlier that a dose of $60 \mathrm{~kg} / \mathrm{ha}$ nitrogen fertilizer was optimum to enhance $\omega 3$ in Indian mustard (Joshi et al., 1998) but it is contradictory to our findings where we found a variation within the same species at N80. $29 \%$ of the genotypes showed an increase in $\omega 3$ by $4.09 \%$ (DRMR-IJ-31) to $27.77 \%$ (DHR-991) over N0 and $71 \%$ of the genotypes reported reduction by $0.06 \%$ (Maya) to $29.54 \%$ (RGN-55) over N0. Previous works have reported the effect of nitrogen only in one genotype and comparative studies have not been explored.

Generally $B$. juncea is known for having all the fatty acids in the ideal range for e.g. high levels of MUFA, low SFA, moderate PUFA, $\omega 6: \omega 3$ ratio of 1.2:1 (Chauhan et al., 2010). Under N0, the $\omega 6: \omega 3$ ranged from 0.91 (NDRE-7) to 1.23 (QM-16) and under N80, it ranged from 0.88 (DRMR-IJ31) to 1.37 (GM-2) (Table 3). According to various medical researchers (Simopoulos, 2012) there is so no ideal $\omega 6: \omega 3$ ratio that would prevent chronological diseases. The optimal ratios vary with the disease under consideration and according to their documentation, ratio beyond 10:1 was observed to have deleterious effects on health (Simopoulos, 2012). However, a low level $\omega 6: \omega 3$ is preferable. It was observed that under N80, $50 \%$ of genotypes had increased the ratio by $0.88 \%$ (HB-9912) to $57.28 \%$ (NDRE-7) over N0. While, $50 \%$ genotypes showed reduction in the ratio by $0.33 \%$ (NRCDR-2) to $11.04 \%$ (Maya) over N0.

The MUFA: PUFA ratio depicting oil stability index (OSI) ranged from 1.23 (HB-9902) to 2.20 (DHR-991) under N0 and from 1.27 (QM-16) to 2.07 (HB-9916) in N80 (Table 3). Most of the genotypes (96\%) failed to reach the ideal range of 2 (Chauhan et al., 2010). However, under N80 about $63 \%$ of genotypes improved in OSI by $1.81 \%$ (GM-2) to 39.54 $\%$ (HB9902) while, the rest $37 \%$ of the genotypes showed reduction by $0.78 \%$ (DRMR-IJ31 ) to $20.90 \%$ (DHR-991) over N0 application.

Nutritionally undesirable erucic acid was found to exceed the recommended percentage of 2\% at both N0 and N80 application (Table 3). Erucic acid, under N80 observed an increase in $63 \%$ of genotypes by $0.9 \%$ (DHR-991) to $38.31 \%$ (HB9902) and $37 \%$ of genotypes showed decrease by $1.14 \%$ (DRMR-IJ 31) to $22.5 \%$ (NRCDR-2) over N0. The variations in nitrogen levels hence contribute to the variation in oil quality as seen in case of composition of individual fatty acids.

\section{Conclusion}

This study showed $\mathrm{N}$ application can bring about changes in oil and seed meal quality. $63 \%$ of the genotypes showed increase in total $\mathrm{N}$ content in seeds by $3 \%$ (DRMR-IJ-31) to $34.0 \%$ (NRCDR-2) and rest $37 \%$ genotypes showed reduction in seed N content by $5.6 \%$ (HB9916) to $20.2 \%$ (EC399300) over control. These genotypes also have positive correlation to the total soluble protein content. However, some genotypes showed an inverse relationship between $\mathrm{N}$ and soluble protein which could be due to the flux in $\mathrm{N}$ to biosynthesis of other carbon compounds as observed by an increase in the case of ascorbic 
acid content and phenol content. Ascorbic acid and total phenolic content showed a positive correlation with TAC $(\mathrm{r}=0.316, \mathrm{p} 0.028)$. Crude fiber and total soluble sugars were observed to decrease under N80. These reductions are desirable for increasing the digestibility and palatability of meal. Seed storage protein profiled under N80 revealed differences in the banding patterns especially in $\alpha$ and $\beta$ chain of the cruciferin which determines the digestibility and quality of seed meal. Fatty acid profiling showed reduction of SFA and $\omega 6: \omega 3$ in $50 \%$ of genotypes and $50 \%$ of genotypes showed increase in their ratios after $\mathrm{N}$ treatment. $63 \%$ of genotypes showed improvement in OSI after N80 treatment. N80 application caused $63 \%$ of the Indian mustard genotypes to increase in erucic acid. Our findings showed application of nitrogen even with recommended dose can influence biochemical changes within same species. All in all our observations suggest that nitrogen fertilizers can play a role in enhancing nutritive status of oilseed Brassica when applied in appropriate doses. Information on the effect of nitrogen application on nutritional status of oil and meal will be quite useful in quality improvement programmes.

Acknowledgements. The authors are grateful to Indian Council of Agricultural Research for providing all the necessary facilities and funding (DRMR-B7) to carry out this work. The authors are grateful to plant breeders for sharing their materials used in this study.

Conflict of interest statement. The authors do not have any conflict of interest.

\section{REFERENCES}

[1] Aires, A., Fernandes, C., Carvalho, R., Bennett, R. N., Saavedra, M. J., Rosa, E. A. (2011): Seasonal effects on bioactive compounds and antioxidant capacity of six economically important Brassica vegetables. - Molecules 16(8): 6816-6832.

[2] AOAC (1955): Official methods of analysis. $16^{\text {th }}$ edn. - Association of official analytical chemists, Washington, DC.

[3] Bala, M., Singh, M. (2013): Non destructive estimation of total phenol and crude fiber content in intact seeds of rapeseed-mustard using FTNIR. - Industrial crops and products 42: 357-362.

[4] Björkman, M., Klingen, I., Birch, A. N., Bones, A. M., Bruce, T. J., Johansen, T. J., Meadow, R., Mølmann, J., Seljåsen, R., Smart, L. E., Stewart, D., (2011): Phytochemicals of Brassicaceae in plant protection and human health - Influences of climate, environment and agronomic practice. - Phytochemistry 72(7): 538-556.

[5] Chakwizira, E., Johnstone, P., Fletcher, A. L., Meenken, E. D., Ruiter, J. M., Brown, H. E. (2015): Effects of nitrogen rate on nitrate-nitrogen accumulation in forage kale and rape crops. - Grass and Forage Science 70(2): 268-282.

[6] Chauhan, J. S., Kumar, S., Singh, K. H., Meena, S. S., Meena, M. L. (2010): Oil and seed meal quality indices of Indian rapeseed-mustard varieties. - Journal of plant biochemistry and biotechnology 19(1): 83-86.

[7] Chopin, F., Orsel, M., Dorbe, M. F., Chardon, F., Truong, H. N., Miller, A. J., Krapp, A., Daniel-Vedele, F. (2007): The Arabidopsis ATNRT2. 7 nitrate transporter controls nitrate content in seeds. - The Plant Cell, 19(5): 1590-1602.

[8] De, S. K., Shanker, J. (1987): Effect of temik 10g and other nitrogen compounds on the contents of vitamins $\mathrm{C}$ and $\mathrm{E}$ in cabbage. - Pesticides 21: 33-37. 
[9] Fallovo, C., Schreiner, M., Schwarz, D., Colla, G., Krumbein, A. (2011): Phytochemical changes induced by different nitrogen supply forms and radiation levels in two leafy Brassica species. - Journal of agricultural and food chemistry 59(8): 4198-4207.

[10] Freyman, S., Toivonen, P. M., Lin, W. C., Perrin, P. W., Hall, J. W. (1991): Effect of nitrogen fertilization on yield, storage losses and chemical composition of winter cabbage. Canadian journal of plant science 71(3): 943-946.

[11] Giorgi, A., Mingozzi, M., Madeo, M., Speranza, G., Cocucci, M. (2009): Effect of nitrogen starvation on the phenolic metabolism and antioxidant properties of yarrow (Achillea collina Becker ex Rchb.). - Food Chemistry 114(1): 204-211.

[12] Groenbaek, M., Jensen, S., Neugart, S., Schreiner, M., Kidmose, U., Kristensen, H. L. (2016): Nitrogen split dose fertilization, plant age and frost effects on phytochemical content and sensory properties of curly kale (Brassica oleracea L. var. sabellica). - Food chemistry 197: 530-538.

[13] Hansen, J., Møller, I. B. (1975): Percolation of starch and soluble carbohydrates from plant tissue for quantitative determination with anthrone. - Analytical biochemistry, 68(1): 87-94.

[14] Hartwig, E. E., Kuo, T. M., Kenty, M. M. (1997): Seed protein and its relationship to soluble sugars in soybean. - Crop Science 37(3): 770-773.

[15] Ibrahim, M. H., Jaafar, H. Z., Rahmat, A., Rahman, Z. A. (2011): Effects of nitrogen fertilization on synthesis of primary and secondary metabolites in three varieties of kacip Fatimah (Labisia pumila Blume). - International Journal of Molecular Sciences 12(8): 52385254.

[16] Joshi, N. L., Mali, P. C., Saxena, A. (1998): Effect of nitrogen and sulphur application on yield and fatty acid composition of mustard (Brassica juncea L.) oil. - Journal of Agronomy and Crop Science 180(1): 59-63.

[17] Khogali, M. E., Dagash, Y. M., EL-Hag, M. G. (2011): Productivity of fodder beet (Beta vulgaris var. Crassa) cultivars affected by nitrogen and plant spacing. - Agric. Biol. JN Am. 2(5): 791-798.

[18] Krober, O. A., Cartter, J. L. (1962): Quantitative interrelations of protein and nonprotein constituents of soybeans. - Crop Science 2(2): 171-172.

[19] Leja, M., Wyzgolik, G., Kaminska, I. (2007): Some parameters of antioxidant capacity of red cabbage as related to different forms of nutritive nitrogen. - Folia Hort. 19(1): 15-23.

[20] Li, J., Zhu, Z., Gerendás, J. (2008): Effects of nitrogen and sulfur on total phenolics and antioxidant activity in two genotypes of leaf mustard. - Journal of Plant Nutrition 31(9): $1642-1655$.

[21] Lisiewska, Z., Kmiecik, W. (1996): Effects of level of nitrogen fertilizer, processing conditions and period of storage of frozen broccoli and cauliflower on vitamin $\mathrm{C}$ retention. Food Chemistry 57(2): 267-270.

[22] Lowry, O. H., Rosebrough, N. J., Farr, A. L., Randall, R. J. (1951): Protein measurement with the Folin phenol reagent. - Journal of biological chemistry 193(1): 265-275.

[23] Nguyen, P. M., Niemeyer, E. D. (2008): Effects of nitrogen fertilization on the phenolic composition and antioxidant properties of basil (Ocimum basilicum L.). - Journal of Agricultural and Food Chemistry 56(18): 8685-8691.

[24] Ochoa-Velasco, C. E., Valadez-Blanco, R., Salas-Coronado, R., Sustaita-Rivera, F., Hernández-Carlos, B., García-Ortega, S., Santos-Sánchez, N. F. (2016): Effect of nitrogen fertilization and Bacillus licheniformis biofertilizer addition on the antioxidants compounds and antioxidant activity of greenhouse cultivated tomato fruits (Solanum lycopersicum L. var. Sheva). - Scientia Horticulturae 201: 338-345.

[25] Paquot, C., Hautfenne, A. (1987): Preparation of the fatty acid methyl esters. - Standard Methods for the Analysis of Oils Fats and Derivatives, 123. 
[26] Parmar, J. K., Parmar, R. M. (2012): Effect of nitrogen and sulphur on quality characteristics and accumulation of some fatty acids in mustard seeds grown under loamy sand soil of North Gujarat. - Asian Journal of Soil Science 7(2): 167-171.

[27] Prieto, P., Pineda, M., Aguilar, M. (1999): Spectrophotometric quantitation of antioxidant capacity through the formation of a phosphomolybdenum complex: specific application to the determination of vitamin E. - Analytical biochemistry 269(2): 337-341.

[28] Qin, C., Qian, W., Wang, W., Wu, Y., Yu, C., Jiang, X., Wang, D., Wu, P. (2008): GDPmannose pyrophosphorylase is a genetic determinant of ammonium sensitivity in Arabidopsis thaliana. - Proceedings of the National Academy of Sciences 105(47): 18308-18313.

[29] Ranganna, S. (1986): Handbook of analysis and quality control for fruit and vegetable products. - Tata McGraw-Hill Education.

[30] Roni, M. S., Zakaria, M., Hossain, M. M., Siddiqui, M. N. (2015): Effect of plant spacing and nitrogen levels on nutritional quality of broccoli (Brassica oleracea L.). - Bangladesh Journal of Agricultural Research 39(3): 491-504.

[31] Shekhawat, K., Rathore, S. S., Premi, O. P., Kandpal, B. K., Chauhan, J. S. (2012): Advances in agronomic management of Indian mustard (Brassica juncea (L.) Czernj. Cosson): An overview. - International Journal of Agronomy, Article ID 408284, doi: http://dx.doi.org/10.1155/2012/408284

[32] Simopoulos, A. P. (2008): The importance of the omega-6/omega-3 fatty acid ratio in cardiovascular disease and other chronic diseases. - Experimental biology and medicine, 233(6): 674-688.

[33] Smoleń, S., Sady, W. (2009): The effect of various nitrogen fertilization and foliar nutrition regimes on the concentrations of sugars, carotenoids and phenolic compounds in carrot (Daucus carota L.). - Scientia Horticulturae 120(3): 315-324.

[34] Sousa, C., Taveira, M., Valentão, P., Fernandes, F., Pereira, J. A., Estevinho, L., Bento, A., Ferreres, F., Seabra, R. M., Andrade, P. B. (2008): Inflorescences of Brassicacea species as source of bioactive compounds: a comparative study. - Food chemistry, 110(4): 953-961.

[35] Suprianto, E. (2014): Genetic variation and inheritance of seed fibre content in winter oilseed rape (Brassica napus L.). - doctoral thesis, Georg-August Universitat, Göttingen, http://hdl.handle.net/11858/00-1735-0000-0022-5EE7-7

[36] Tavarini, S., Pagano, I., Guidi, L., Angelini, L. G. (2016): Impact of nitrogen supply on growth, steviol glycosides and photosynthesis in Stevia rebaudiana Bertoni. - Plant Biosystems-An International Journal Dealing with all Aspects of Plant Biology 150(5): 953962.

[37] Wanasundara, J. P. (2011): Proteins of Brassicaceae oilseeds and their potential as a plant protein source. - Critical reviews in food science and nutrition 51(7): 635-677.

[38] Wanasundara, J. P., Abeysekara, S. J., McIntosh, T. C., Falk, K. C. (2012): Solubility differences of major storage proteins of Brassicaceae oilseeds. - Journal of the American Oil Chemists' Society 89(5): 869-881.

[39] Yu, P. (2008): Molecular chemistry of plant protein structure at a cellular level by synchrotron-based FTIR spectroscopy: Comparison of yellow (Brassica rapa) and Brown (Brassica napus) canola seed tissues. - Infrared Physics and Technology 51(5): 473-481.

[40] Zaghdoud, C., Carvajal, M., Moreno, D. A., Ferchichi, A., del Carmen Martínez-Ballesta, M. (2016): Health-promoting compounds of broccoli (Brassica oleracea L. var. italica) plants as affected by nitrogen fertilisation in projected future climatic change environments. - Journal of the Science of Food and Agriculture 96(2): 392-403.

[41] Zambiazi, R. C., Przybylski, R., Zambiazi, M. W., Mendonça, C. B. (2007): Fatty acid composition of vegetable oils and fats. - B. ceppa, curitiba 25(1): 111-120. 